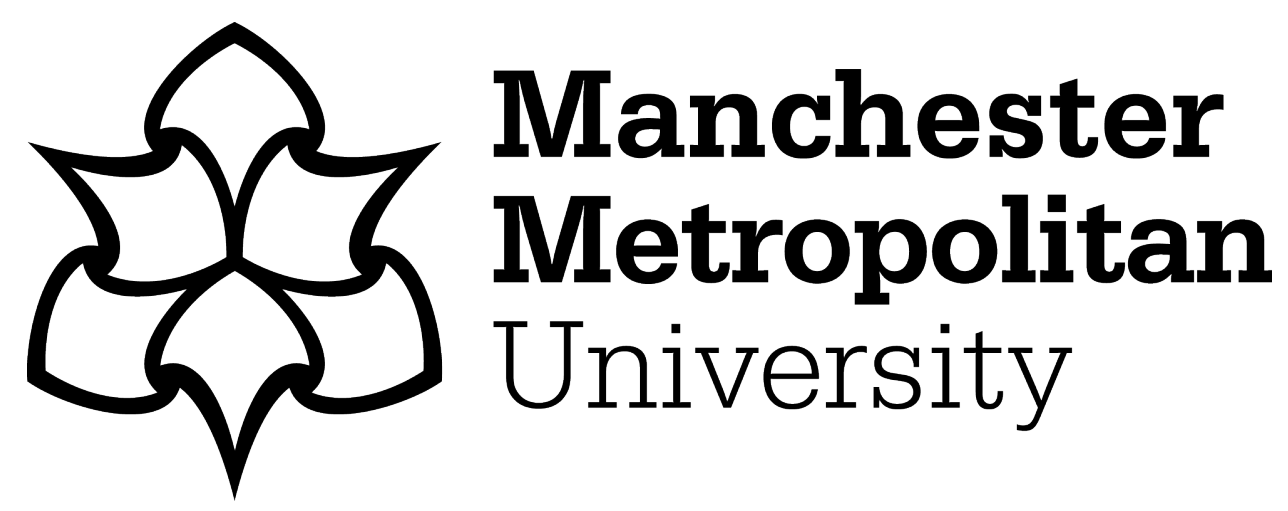

Tomkins, M, Dortch, J, Hughes, P, Huck, J, Tonkin, T and Barr, ID (2018) Timing of glacial retreat in the Wicklow Mountains, Ireland, conditioned by glacier size and topography. Journal of Quaternary Science, 33 (6). pp. 611623. ISSN 0267-8179

Downloaded from: https://e-space.mmu.ac.uk/620438/

Publisher: Wiley

DOI: https://doi.org/10.1002/jqs.3040

Please cite the published version 


\section{Journal of Quaternary Science}

\section{Timing of glacial retreat in the Wicklow Mountains, Ireland, conditioned by glacier size and topography}

\begin{tabular}{|r|l|}
\hline Journal: & Journal of Quaternary Science \\
\hline Manuscript ID & JQS-17-0106 \\
\hline Wiley - Manuscript type: & Research Article \\
\hline Date Submitted by the Author: & 23-Nov-2017 \\
\hline Complete List of Authors: & $\begin{array}{l}\text { Tomkins, Matt; University of Manchester School of Environment and } \\
\text { Development, } \\
\text { Dortch, Jason; University of Manchester School of Environment and } \\
\text { Development } \\
\text { Hughes, Philip; University of Manchester School of Environment and } \\
\text { Development } \\
\text { Huck, Jonny; University of Manchester School of Environment and } \\
\text { Development } \\
\text { Tonkin, Toby; University of Derby, Department of Natural Sciences } \\
\text { Barr, Iestyn; Manchester Metropolitan University, School of Science and } \\
\text { the Environment }\end{array}$ \\
\hline Keywords: & $\begin{array}{l}\text { Schmidt Hammer exposure dating (SHED), Wicklow, Ireland, Glacier } \\
\text { chronology, Topographic controls, <sup >10</sup >Be dating }\end{array}$ \\
\hline
\end{tabular}

\section{SCHOLARONE"}

Manuscripts 


\title{
Timing of glacial retreat in the Wicklow Mountains, Ireland, conditioned by glacier size and topography
}

\author{
Matt D. Tomkins* ${ }^{1}$ Jason D. Dortch, ${ }^{1}$ Philip D. Hughes, ${ }^{1}$ Jonny J. Huck, ${ }^{1}$ Toby N. \\ Tonkin $^{2}$ and Iestyn D. Barr ${ }^{3}$ \\ *Corresponding author (matthew.tomkins@postgrad.manchester.ac.uk) \\ ${ }^{1}$ Department of Geography, School of Environment, Education and Development, The \\ University of Manchester, Manchester, M13 9PL, UK \\ ${ }^{2}$ Department of Natural Sciences, University of Derby, Kedleston Road, Derby, DE22 1GB, UK \\ ${ }^{3}$ School of Science and the Environment, Manchester Metropolitan University, Chester Street, \\ Manchester, M1 5GD, UK
}

\begin{abstract}
This paper presents 170 Schmidt Hammer exposure ages from moraine boulders and glacially-sculpted bedrock to reveal the post-Last Glacial Maximum (LGM) history of the Wicklow Mountains, Ireland. These data suggest that large ice masses survived for 4-7 ka after retreat of the Irish Sea Ice Stream and were sustained by summit ice-fields until 16.6 ka. Post-LGM retreat was dynamic, with re-advance moraines deposited in response to Heinrich Stadial 1 . However, these events reflect short-term ice front oscillations ( $\leq 1 \mathrm{ka})$ during the long-term retreat phase. Retreat from re-advance positions was synchronous across the range and paced by climate, with time-progressive deglaciation from low to high elevation. In contrast, marked asynchroneity in the timing of Younger Dryas deglaciation is closely linked to snow redistribution and indicates that for small cirque glaciers $\left(\leq 1 \mathrm{~km}^{2}\right)$, topography can exert the primary control on glacier survival. This result has important implications for palaeoclimate reconstructions as cirque glacier dynamics may be unrelated to climate. This is further complicated by post-depositional processes which can result in moraine ages (e.g. ${ }^{10} \mathrm{Be}$ ) which post-date retreat. Future palaeoclimate studies should prioritise cirque glaciers where snow contributing areas are small and where postdepositional disturbance is limited (matrix-poor, boulder-rich moraines).
\end{abstract}

\section{Keywords}

- Schmidt Hammer exposure dating (SHED)

- Wicklow, Ireland 
- Glacier chronology

- Topographic controls

- ${ }^{10}$ Be dating

\section{Introduction}

Recent studies have focused on the retreat dynamics of the Irish Sea Ice Stream (ISIS) (Chiverrell et al., 2013; Smedley et al., 2017a), a major outlet of the British-Irish Ice Sheet (BIIS; Smedley et al., 2017b). The timing of ISIS retreat after the Last Glacial Maximum (LGM; 23.3 $27.5 \mathrm{ka}$; Hughes and Gibbard, 2015) has important implications for the dynamics of terrestrial ice masses and, in particular, proximal mountain ice caps (Clark et al., 2012). In the Irish Sea Basin, ice caps centred on the mountains of Wales (Hughes et al., 2016), the Lake District (Wilson et al., 2013) and Wicklow, Ireland (Ballantyne et al., 2006) coalesced with the ISIS during the LGM and may have persisted after ISIS retreat. However, while the deglacial chronologies of the Welsh and Lake District ice caps are constrained by ${ }^{10} \mathrm{Be}$, OSL and ${ }^{14} \mathrm{C}$ ages (Ballantyne et al., 2009; McCarroll et al., 2010; Glasser et al., 2012; Lloyd et al., 2013; Hughes et al., 2016; Smedley et al., 2017b), there is a paucity of geomorphological and geochronological evidence for post-LGM activity in the Wicklow Mountains. ${ }^{10}$ Be ages from summits in Wicklow (Ballantyne et al., 2006) and the adjacent Blackstairs Mountains (Ballantyne and Stone, 2015) indicate summit deglaciation soon after the LGM ( $n=5 ; 21.0$ $22.9 \mathrm{ka})$, while a single ${ }^{36} \mathrm{Cl}$ age from the Mottee Stone ( $20 \mathrm{~km}$ SE of Lugnaquilla $(925 \mathrm{~m})$ at $52.886993,-6.208196)$ indicates separation of mainland ice and the ISIS by $23.1 \pm 2.2 \mathrm{ka}$ (Bowen et al., 2002). This timeframe accords with Bayesian modelling of ice stream retreat, with the ISIS retreating $\sim 80 \mathrm{~km}$ along the Irish coast during the interval $20.8-23.9 \mathrm{ka}$ (Smedley et al., 2017b). Recent research has begun to establish the geomorphological context for deglaciation in the Wicklow Mountains (Knight et al., 2017). However with the exception of isolated ${ }^{14} \mathrm{C}\left(\mathrm{n}=2,11.5-11.6 \mathrm{ka}\right.$; Colhoun and Synge, 1980) and ${ }^{36} \mathrm{Cl}$ ages $(\mathrm{n}=$ $1 ; 17.9 \pm 1.0 \mathrm{ka}$; Bowen et al., 2002) from Lough Nahanagan, the geochronology of the deglaciation of the Wicklow Ice Cap is poorly understood. To address this knowledge gap, this study presents 170 Schmidt Hammer (SH) exposure ages from cirque and valley moraines and from a summit overridden by ice at the LGM. These data provide new insights into the contrasting deglacial chronologies of the ISIS and the Wicklow Ice Cap and the climatic and topographic factors which conditioned post-LGM retreat.

\section{Methods}


To develop a deglacial chronology, sampling was focused on prominent moraines and boulder accumulations as these are the best geomorphological indicators of the dimensions of former mountain glaciers (Barr et al., 2017). Key sites along the main SW-NE axis of the mountain range were targeted for Schmidt Hammer exposure dating (SHED; Tomkins et al., 2016) including glacially-deposited boulders on prominent cirque moraines (>400 m) at Kelly's Lough, Lough Nahanagan, Mullaghcleevaun and Upper Lough Bray. These moraines exhibit good spatial coherence (Kirkbride and Winkler, 2012) as they are generally matrixpoor, boulder-rich and feature clearly defined moraine crests, although the outer cirque moraine at Lough Nahanagan is degraded (Colhoun and Synge, 1980). This moraine is $\sim 1 \mathrm{~km}$ in length, broadly convex in cross-profile form and consists of unsorted granite, sand and gravel deposits with entrained glacially smoothed granite boulders ( 1 - $4 \mathrm{~m}$ diameter; Colhoun and Synge, 1980). Multiple nested moraines and boulder accumulations are preserved within the inferred YD glacial limit at each site, which conforms to a pattern of active oscillatory retreat (Bickerdike et al., 2017). In addition, samples were obtained from valley moraines (250 - 400 m, c. 2 - 4 km from cirque headwalls) at Carrawaystick Brook, Upper Glendasan, Lough Brook and Glenmacnass Waterfall and from ice-moulded bedrock and erratic boulders from the summit of Carrigshouk $(571 \mathrm{~m})$, which was overridden by ice at the LGM (Fig. 1; Table 1). 20 surfaces were sampled at each site (Carrawaystick Brook; $n=10$ ) and 170 surfaces were sampled in total, comparable to previous applications of SHED in the Mourne Mountains, Northern Ireland (Barr et al., 2017).

30 R-values were generated per surface (Niedzielski et al., 2009). Sampled boulders were of sufficient size (> 25 kg; Sumner and Nel, 2002; Demirdag et al., 2009) and all sampled surfaces were free of surface discontinuities (Williams and Robinson, 1983) and lichen (Matthews and Owen, 2008). Instrument calibration (Correction Factor $=1.017$ ) and age calibration (Correction Factor $=0.992$ ) were performed using the SHED-Earth online calculator (http://shed.earth) following the recommendations of Dortch et al. (2016). SH exposure ages and $1 \sigma$ uncertainties were calculated based on the arithmetic mean for each surface (Mean of 30 R-values) and based on the updated calibration curve of Tomkins et al. (2017) which includes ${ }^{10} \mathrm{Be}$ dated surfaces from Blackstairs Mountain, Wexford $(\mathrm{n}=2$; Ballantyne and Stone, 2015) and Bloody Foreland, Donegal ( $n=6$; Ballantyne et al., 2007; Clark et al., 2009). These data fit the trend established at calibration sites in Scotland and NW England and indicate that errors in $\mathrm{SH}$ exposure age estimates due to climatic variability appear unlikely (Barr et al., 2017). Calibration site exposure ages are calculated using the online calculators formerly known as the CRONUS-Earth online calculator (http://hess.ess.washington.edu/math/, Wrapper script 2.3, Main calculator 2.1, constants 2.3, muons 1.1; Balco et al., 2008) and are based on the time-dependent Lm scaling (Lal, 1991; Stone, 2000), the Loch Lomond Production Rate (LLPR; Fabel et al., 2012; $4.02 \pm 0.18$ atoms $\mathrm{g}^{-1} \mathrm{a}^{-1}$ ) and assuming $0 \mathrm{~mm} \mathrm{ka}{ }^{-1}$ erosion. The LLPR is constrained by independent ${ }^{14} \mathrm{C}$ ages (MacLeod et al., 2011) and is the most widely used local production rate in the British Isles. However, the results presented here will be subject to recalibration in light of future refinement of local production rates. For each sampled site $(n=9)$, probability density 
estimates (PDEs) were produced and modelled to separate out the highest probability Gaussian (Fig. 2; Dortch et al., 2013) to account for geological uncertainty. This analytical method has been employed in studies using ${ }^{10} \mathrm{Be}$ (Dortch et al., 2013; Murari et al., 2014) to identify ages that are too young (moraine degradation; Heyman et al., 2011) or too old (inheritance; Hallet and Putknonen, 1994).

Based on the results of SHED, three dimensional reconstructions of cirque glaciers were generated using the GLaRe tool (Pellitero et al., 2016; Basal shear stress $=100 \mathrm{kPa}$; Step length $=10 \mathrm{~m}$ ) and used to estimate palaeo equilibrium-line altitudes (ELAs). Valley glaciers were also reconstructed for individual catchments using this method although ELAs were not calculated for these ice configurations as geochronological data are not available for all glacier outlets. ELAs were estimated using the GIS tool of Pellitero et al. (2015), applying the area-altitude balance ratio method (AABR = $1.9 \pm 0.81$; Rea, 2009). ELAs are controlled by climate (Ohmura et al., 1992; Hughes and Braithwaite, 2008) but are also strongly influenced by non-climatic factors (Table 2), such as the supply of snow and ice from indirect sources (Mitchell, 1996; Kern and Laszlo, 2010). To assess the impact of 'redistributed' snow and ice, combined snow and avalanche contributing areas $\left(A_{c}\right)$ were calculated (c.f. Ballantyne, 2007a,b; Barr et al., 2017; Dominant wind direction W/SW $=210-300^{\circ}$, Avalanche slopes $\geq$ $25^{\circ}$ ) and compared to total glacier surface areas $\left(A_{g}\right)$. The $A_{c} / A_{g}$ ratio is a proxy for the potential contribution of redistributed snow to glacier accumulation.

\section{Results}

Gaussian SH exposure ages (Table 1) are in correct stratigraphic order in individual glacier catchments, are broadly consistent with comparable deglacial chronologies across the British Isles (Clark et al., 2012), and clearly differentiate cirque and valley moraines, with deposition during the Younger Dryas (YD; 11.7 - 12.9 ka) and Oldest Dryas respectively (GS-2.1a; 14.7 $17.5 \mathrm{ka}$ ). Moreover, these datasets are chronologically robust (Kirkbride and Winkler, 2012), with well-dated moraine sequences in Glenmalur, Glendasan and Glenmacnass (Fig. 1), and provide a framework for a wider morphostratigraphic deglacial chronology for the Wicklow Mountains (Knight et al., 2017). At cirque sites, SHED indicates deglaciation by $12.31 \pm 0.51$ ka at Upper Lough Bray (ULB), $12.00 \pm 0.44$ ka at Kelly's Lough (KL), $11.40 \pm 0.13$ ka at Mullaghcleevaun (MC) and $10.93 \pm 0.26$ ka for the outer moraine at Lough Nahanagan (LN; Colhoun and Synge, 1980). In contrast, valley moraines were deposited at $16.46 \pm 0.58 \mathrm{ka}$ at Glenmacnass Waterfall (GW), $16.21 \pm 0.60 \mathrm{ka}$ at Upper Glendasan, $15.48 \pm 0.35 \mathrm{ka}$ at Carrawaystick Brook (CB) and $15.41 \pm 0.30 \mathrm{ka}$ at Lough Brook (LB). Finally, SHED indicates the emergence of Carrigshouk (CS) by $16.64 \pm 0.82 \mathrm{ka}$. This date provides a minimum age for wider summit deglaciation in the Wicklows Mountains due to its comparatively low elevation (571 $\mathrm{m}$ ) and central position on the range divide. Reconstructed cirque glaciers (Table 2) range in size from $0.35 \mathrm{~km}^{2}$ (ULB) to $1.10 \mathrm{~km}^{2}(\mathrm{LN})$ while snow contributing areas $\left(A_{c}\right)$ range 
from $0.12 \mathrm{~km}^{2}$ (ULB) to $1.07 \mathrm{~km}^{2}$ (LN). At Lough Nahanagan and Mullaghcleevaun, extensive upland plateaus to the west and south $\left(210-300^{\circ}\right)$ account for large snow contributing areas $\left(A_{c} \geq 1 \mathrm{~km}^{2}\right)$. In contrast, restricted upslope areas within the glacier drainage basin likely limited the potential for significant snow redistribution $\left(A_{c} \leq 0.5 \mathrm{~km}^{2}\right)$ at Kelly's Lough and Upper Lough Bray. AABR ELAs for cirque glaciers range from $513 \mathrm{~m}$ (LN) to $648 \mathrm{~m}(\mathrm{KL})$ and show no clear spatial clustering. Finally, reconstructed valley glaciers range in size from 4.96 $\mathrm{km}^{2}$ (UGD) to $12.46 \mathrm{~km}^{2}$ (GW) and demonstrative a progressive reduction in total glacier area $\left(A_{g}\right)$ throughout the period $15.4-16.5 \mathrm{ka}$.

\section{Discussion}

Firstly, these data demonstrate that significant ice masses persisted in the Wicklows after retreat of the ISIS, with large valley glaciers (Length: $\sim 4 \mathrm{~km}$, Area: $\sim 12.5 \mathrm{~km}^{2}$ ) present until the onset of the Late-glacial (Greenland Interstadial-1; Rasmussen et al., 2014). While lowland $(23.1 \pm 2.2$ ka; Bowen et al., 2002) and summit deglaciation ( $n=3 ; 21.0-21.9$ ka; Ballantyne et al., 2006) was coeval with ISIS retreat (Smedley et al., 2017b), SH exposure ages from the summit of Carrigshouk (571 m) indicate that summit ice fields were present on the range divide until $16.64 \pm 0.82 \mathrm{ka}$. However, distal summits were ice free as early as $21.9 \pm 1.1 \mathrm{ka}$ (Djouce Mountain, $725 \mathrm{~m}$ ), $21.2 \pm 1.1 \mathrm{ka}$ (Scarr, $641 \mathrm{~m}$ ) and $21.0 \pm 1.1 \mathrm{ka}$ (Kanturk, $523 \mathrm{~m}$ ) and evidence a significant time lag in summit deglaciation $(\sim 4.4 \mathrm{ka})$. Collectively, ${ }^{10} \mathrm{Be}$ and SHED ages indicate rapid downwastage of the Wicklow Ice Cap soon after the LGM and a transition to summit ice fields which sourced discrete outlet glaciers (e.g. Glenmacnass, Glendasan, Glenmalur; Fig. 1). This chronology is consistent with ${ }^{10} \mathrm{Be}$ ages from summits in Wales (Glasser et al., 2012; Hughes et al., 2016), which record downwastage of the Welsh Ice Cap at $19-20 \mathrm{ka}(\leq 600 \mathrm{~m})$, while ${ }^{14} \mathrm{C}$ ages from proximal Welsh lowlands $(15.82 \pm 0.39 \mathrm{cal}$. ka BP; Lowe, 1981; Reimer et al., 2013), show that Alpine-style valley glaciers were present for $\sim 4$ ka after initial summit emergence (Hughes et al., 2016). These data also accord with a ${ }^{36} \mathrm{Cl}$ age from ice-sculpted bedrock in the Scafell massif, which indicates substantial downwastage of the Lake District ice cap by $17.3 \pm 1.1 \mathrm{ka}$ (<750 m; Ballantyne et al., 2009). Deglaciation of Carrigshouk at $\sim 16.6$ ka marks a shift to topographically confined ice flow, with glaciers sourced from high elevation cirques, and likely reflects a time-progressive response to reduced moisture availability and winter aridity during this interval (Kelly et al., 2010). However, these data indicate that summit ice fields and large valley glaciers persisted in the Wicklows for 4 - 7 ka after ISIS retreat (Smedley et al., 2017b), and reveal similarities in the post-LGM histories of the Wicklow, Welsh (Hughes et al., 2016) and Lake District ice caps (Ballantyne et al., 2009). These data accord with wider evidence for post-LGM disintegration of the BIIS into component ice caps (Clark et al., 2012).

Secondly, the geomorphological record indicates that post-LGM retreat was dynamic, with valley and cirque re-advance moraines deposited during the Oldest Dryas and Younger 
Dryas respectively (Fig. 2A). Re-advance of valley glaciers during the interval $15.4-16.5 \mathrm{ka}$ was coeval with peak ice rafted debris flux (Bard et al., 2000; Eynaud et al., 2009) and reduced sea surface temperatures (Bard et al., 2000) during Heinrich Stadial 1 (Fig. 2B; HS1) and the re-advance of the Irish Ice Sheet (IIS) and the ISIS during the Killard Point Stadial ( $16-17.1$ ka; McCabe et al., 2007; Clark et al., 2012). The re-advance of glaciers in Ireland during the Oldest Dryas was matched further down the North-East Atlantic margin in Spain (Palacios et al., 2017). These re-advances are linked to North Atlantic climate perturbations (HS1) and likely reflect short-term oscillations of the ice front $(\leq 1 \mathrm{ka})$ during the long-term post-LGM retreat phase ( $8 \mathrm{ka})$. Moreover, these chronological data match recent morphostratigraphic assessments which support a widespread pattern of sustained retreat interrupted by minor glacier readvance (Knight et al., 2017). Retreat from re-advance positions, estimated at 1.82 $\mathrm{km} \mathrm{ka}^{-1}$ for the Glenmacnass glacier, was synchronous across the Wicklow Mountains, as demonstrated by progressive deglaciation from low to high elevation (Fig. $3 \mathrm{~A} ; \mathrm{R}^{2}=0.9116 ; p$ $=0.045$ ). These data are indicative of climate-controlled retreat with independent outlet glaciers responding synchronously to reduced moisture availability (Kelly et al., 2010), irrespective of contrasting glacier aspects, source areas or glacier extents. Oldest Dryas valley glaciers were extensive $\left(\leq 12.5 \mathrm{~km}^{2}\right)$, sustained by ice fields and prior to $\sim 16.6 \mathrm{ka}$, overtopped low-lying summits $(\sim 571 \mathrm{~m})$. As a result, the potential for significant redistribution of snow and avalanche material ( $\mathrm{Ac}>\mathrm{Ag}$ ) was limited, particularly during periods of winter aridity (Kelly et al., 2010). Therefore, while topography likely influenced the retreat pattern in individual valleys, post-LGM retreat $(\sim 15-17 \mathrm{ka})$ was primarily paced by climate.

In contrast, marked asynchroneity in the timing of final YD deglaciation (Fig. 3; $11.4-12.3 \mathrm{ka}$ ) is unrelated to cirque elevation (Fig. $3 \mathrm{~A} ; \mathrm{R}^{2}<0.01, p=0.97$ ), palaeo-ELA (Fig. 3E; $\mathrm{R}^{2}=0.04, p$ $=0.81)$ or site latitude $\left(R^{2}=0.10, p=0.69\right)$. These data suggest that climate was not the dominant control on the timing of final YD deglaciation. Instead, glacier retreat was strongly controlled by local topography and the redistribution of wind-blown snow and avalanche material (Fig. 3B; $\mathrm{R}^{2}>0.99, p<0.01$ ). Combined snow and avalanche contributing areas $\left(\mathrm{A}_{c}\right)$ range from just $0.119 \mathrm{~km}^{2}$ at Upper Lough Bray to $1.071 \mathrm{~km}^{2}$ at Lough Nahanagan. For glaciers with large $A_{c}$ areas, topography may exert the primary control on glacier formation and survival, and may account for the comparatively late-deglaciation of Lough Nahanagan and Mullaghcleevaun during the early-Holocene. By comparison, glaciers with small $A_{c}$ areas, where the potential for redistribution of snow and avalanche material is limited, may respond quasi-synchronously to climate warming. For example, the early deglaciation of Upper Lough Bray at $12.31 \pm 0.51 \mathrm{ka}$ is coeval with a gradual rise is summer air temperatures after $\sim 12.5$ ka (Brooks and Birks, 2000) which was likely sufficient to raise the 'climatic' ELA above cirque elevations $\left(A_{c} / A_{g}=0\right.$; Barr et al., 2017) and initiate mass wastage. In contrast, abundant snow redistribution $\left(A_{c} \geq 1\right)$, conditioned by existing topographic configurations (extensive upland plateaus), was likely sufficient to locally supress the 'local' (non-climatic) ELA and promote glacier survival at other sites. However, the contribution of redistributed snow to glacier accumulation almost certainly diminished throughout the YD as summer air temperatures 
increased rapidly towards the onset of the Holocene (Brooks and Birks, 2000), thus limiting snowpack preservation. These data indicate that while regional climate provides the baseline conditions for glacier growth and decay, cirque glacier dynamics may primarily reflect the influence of topography. However, there is a weak correlation between glacier size $\left(A_{g}\right)$ and deglaciation age (Fig. $3 C ; R^{2}=0.77, p=0.12$ ), although the size variation between the smallest (ULB; $0.35 \mathrm{~km}^{2}$ ) and largest reconstructed glacier (LN: $\left.1.10 \mathrm{~km}^{2}\right)$ is minimal $(\sim 0.75$ $\mathrm{km}^{2}$ ). As such, significant within-mountain range variation in glacier response times is not anticipated (Raper and Braithwaite, 2009). This may account for the weak correlation between $A_{c} / A_{g}$ ratios and deglaciation ages (Fig. $3 D_{;} R^{2}=0.58, p=0.24$ ) although the observable trend demonstrates the probability of early deglaciation for glaciers with small $A_{c} / A_{g}$ ratios. Based on this reasoning, we conclude that for small YD glaciers, local topoclimatic controls can be more significant than wider regional climate in determining cirque glacier dynamics, and in particular, the timing of final deglaciation. This result has important implications for palaeoclimate reconstructions based on dating of cirque moraines (e.g. using ${ }^{10} \mathrm{Be}$ ), as cirque glacier ELAs are not representative of the regional climate and consequently glaciers dynamics are likely to be decoupled from climatic changes occurring in the North Atlantic region. This phenomenon is observed today in the behaviour of small glaciers in marginal glaciated settings such as the Italian Alps (Colucci, 2016) and other Mediterranean mountains (Hughes, 2018). These data from Ireland also show that the impact of topography on glacier dynamics is most significant when glaciers are small $\left(\leq 1 \mathrm{~km}^{2}\right)$, resulting in clear asynchroneity in deglaciation (Fig. $3 A ; R^{2}=<0.01$ ), and provide further evidence that the climatic integrity of cirque glaciers may be limited (Kirkbride and Winkler, 2012). In contrast, large glaciers $\left(\sim 12.5 \mathrm{~km}^{2}\right)$, with limited potential for snow redistribution, have been shown to respond synchronously to climate forcing (Fig. $3 A ; R^{2}=0.9116$ ). Modelling studies have shown that topoclimatic variables (solar radiation/snow redistribution) can predict the style of deglaciation (moraine distribution) for small Younger Dryas glaciers (Coleman et al., 2009; Bickerdike et al., 2017). The chronological data presented here provides new evidence that topographic controls not only influence the style of deglaciation, but can determine the timing of final deglaciation, with clear withinmountain range variability.

A further challenge in linking cirque glacier dynamics to climatic fluctuations is the potential impact of moraine stabilisation (Hallet and Putknonen, 1994). This post-depositional process can result in moraine ages (e.g. ${ }^{10} \mathrm{Be}$ ) which post-date glacial retreat. A 1-2 ka early stabilization period has been recorded for Alpine moraine sequences in Alaska and the Alps (Briner et al., 2005; Ivy-Ochs et al., 2006, 2008; Dortch et al., 2010a). In these environments, glaciers can produce distinctive asymmetric ice-contact fans that undergo rapid gullying and post-depositional reworking on their ice-proximal slopes (e.g. Hambrey et al., 2012; Lukas et al., 2012). However, these landforms are topographically and sedimentologically distinct from the low-relief, topographically concordant valley and cirque landsystems found in the Wicklow Mountains. Moreover, there has been comparatively little attention to processes of moraine development and deglaciation dynamics in these environments, with analogue 
studies predominantly focused on 'hummocky moraine' landsystems (e.g. Benn and Lukas, 2006), and a relative paucity of research into moraine processes in smaller cirque type landsystems, likely under the assumption of rapid stabilisation after deglaciation. Recent work has highlighted the importance of self-censoring in cirque environments due to obliterative overlap (Barr and Lovell, 2014) or ice-cored moraine degradation (Crump et al., 2017; Tonkin et al., 2017), while external-censoring due to slope instability may also provide a control on moraine stabilisation (Barr and Lovell, 2014). As a result, there is considerable uncertainty regarding the robustness of chronological datasets for cirque moraine systems (Kirkbride and Winkler, 2012). To produce better-resolved glacier chronologies, researchers can account for moraine stabilisation through (1) morphostratigraphic comparison of moraine sequences, (2) Gaussian separation of exposure ages (Dortch et al., 2013), (3) assessment against independent geochronological data (e.g. ${ }^{14} \mathrm{C}, \mathrm{OSL}$ ) and (4) consideration of modern process studies and likely modern analogues for moraine assemblages when assessing site suitability for a give geochronological approach (e.g. Çiner et al. 2015). Based on these criteria, we infer that moraine stabilisation may be a key post-depositional process for the outer moraine at Lough Nahanagan. Firstly, this moraine is degraded (Colhoun and Synge, 1980) and is morphologically distinct from sampled cirque moraines at Mullaghcleevaun, Kelly's Lough and Upper Lough Bray which are tall (> $3 \mathrm{~m}$ ), matrix-poor, boulder-rich, and feature clearly defined moraine crests (Fig. 4). Secondly, Gaussian separation of SHED data for this site $(n=20)$ reveals a clear 'two-peak' probability density function (Fig. 2C), with Gaussian ages of $10.93 \pm 0.26 \mathrm{ka}(\mathrm{n}=9)$ and $11.38 \pm 0.26 \mathrm{ka}(\mathrm{n}=9)$. The youngest age post-dates the YD by $\sim 0.8 \mathrm{ka}$ and is inconsistent with wider evidence for deglaciation of the British Isles by the YD/Holocene transition (MacLeod et al., 2011) although in isolation, this observation is insufficient to reject this age at this stage. In addition, this method highlights clear outlier ages ( $n=3 ; 12.8-13.5 \mathrm{ka}$ ). These Gaussian ages can be rejected as they are comprised of fewer than 3 ages (c.f. Fig. 3 in Dortch et al., 2013). Finally, independent ${ }^{14} \mathrm{C}$ ages indicate deglaciation during the late $\mathrm{YD}$ and early Holocene (11.5 - 11.6 ka; Colhoun and Synge, 1980). In contrast, a single ${ }^{36} \mathrm{Cl}$ age suggests ice free conditions since $17.9 \pm 1.0 \mathrm{ka}$ (Bowen et al., 2002), although this age likely reflects prior exposure (inheritance) and is rejected from further analysis. Based on these data, we conclude that the older Gaussian age of $11.38 \pm 0.26 \mathrm{ka}$ is more representative of final deglaciation as this age is consistent with previous ${ }^{14} \mathrm{C}$ ages and accounts for both the distinctive geomorphological assemblage at this site and the clear 'two-peak' distribution of SHED ages. This conclusion indicates that moraine stabilisation and boulder exhumation may account for the degraded moraine surface and comparatively 'young' SHED ages. These data provide further evidence that moraine ages are more likely influenced by post-glacial instability than prior exposure (Shanahan \& Zreda 2000; Putkonen \& Swanson 2003; Zech et al. 2005; Heyman et al. 2011; Applegate et al., 2012). As a result, the dynamics of small cirque glaciers $\left(<1 \mathrm{~km}^{2}\right)$, as determined by radiometric methods $\left({ }^{10} \mathrm{Be}\right)$, may not only primarily reflect topographic controls, but may be profoundly influenced by post-depositional processes. The post-depositional evolution of YD moraine systems is largely unexplored at 
present and a clear co-benefit of the SHED approach is the potential insight into these processes; insight that was not afforded by other geochronological approaches. Future research should carefully consider landform context (Barr and Lovell, 2014) and prioritise sampling of cirque environments where snow and avalanche contributing areas $\left(A_{c}\right)$ are small (Warren, 1991; Mills et al., 2012; Barr and Lovell, 2014), where postglacial erosion is limited and where short transport distances promote the formation of matrix-poor boulder-rich moraines (Fig. 5; Pallàs et al., 2010). In these environments, snow redistribution is limited and moraines are more likely to stabilise rapidly after deglaciation. As such, these glaciers may respond quasi-synchronously to climatic fluctuations and may produce more robust palaeoclimatic reconstructions.

\section{Conclusions}

This study provides the first chronological constraints on post-LGM retreat of the Wicklow Ice Cap. $170 \mathrm{SH}$ exposure ages from cirque and valley moraines and from a summit overridden by ice at the LGM demonstrate that significant ice masses persisted in the Wicklows after retreat of the ISIS and were sustained by summit ice-fields until $16.6 \mathrm{ka}$. Post-LGM retreat was dynamic, with re-advance moraines deposited during the Oldest Dryas in response to HS1 cooling. However, these events reflect short-term oscillations ( $\leq 1 \mathrm{ka})$ of the ice front during the long-term retreat phase $(\sim 8 \mathrm{ka})$, which was driven by reduced moisture availability and winter aridity. This chronology is matched by ${ }^{10} \mathrm{Be}$ and ${ }^{14} \mathrm{C}$ ages from the Welsh Ice Cap, with downwastage during the interval 19-20 ka, while alpine valley glaciers persisted for $\sim 4$ ka after initial summit emergence. Retreat from re-advance positions was paced by climate, with time-progressive deglaciation from low to high elevation $\left(R^{2}=0.9116\right)$. In contrast, asynchroneity in final Younger Dryas deglaciation is accounted for by local topography and the redistribution of snow and avalanche material. Contrasting synchroneity in the timing of glacial retreat during these periods is conditioned by glacier size, with small YD glaciers $\left(<1 \mathrm{~km}^{2}\right)$ highly sensitive to local topographic controls. This result has important implications for palaeoclimate reconstructions based on dating of cirque moraines (e.g. ${ }^{10} \mathrm{Be}$ ), as cirque glacier dynamics may be unrelated to climate. This is further complicated by post-depositional processes which can result in ages which post-date retreat. As a result, future palaeoclimate reconstructions should prioritise cirque glaciers where snow and avalanche contributing areas $\left(A_{c}\right)$ are small and where the potential for post-depositional disturbance is limited (matrix-poor, boulder rich moraines).

\section{Acknowledgements}

MT is funded by a University of Manchester Presidents Doctoral Scholarship. Fieldwork was funded by the University of Manchester School of Environment, Education and Development 
Fieldwork Support Fund. We would like to thank D. Tomkins for fieldwork support and D. Fabel for kindly providing unpublished calibration data for the LLPR.

\section{References}

Applegate PJ, Urban NM, Keller K, Lowell T V, Laabs BJC, Kelly MA, Alley RB. 2012. Improved moraine age interpretations through explicit matching of geomorphic process models to cosmogenic nuclide measurements from single landforms. Quaternary Research 77: 293-304.

Balco G, Stone JO, Lifton NA, Dunai TJ. 2008. A complete and easily accessible means of calculating surface exposure ages or erosion rates from ${ }^{10} \mathrm{Be}$ and ${ }^{26} \mathrm{Al}$ measurements. Quaternary Geochronology 3: 174-195.

Ballantyne CK. 2007a. Loch Lomond Stadial glaciers in North Harris, Outer Hebrides, North-West Scotland: glacier reconstruction and palaeoclimatic implications. Quaternary Science Reviews 26: 3134-3149.

Ballantyne CK. 2007b. The Loch Lomond Readvance on north Arran, Scotland: glacier reconstruction and palaeoclimatic implications. Journal of Quaternary Science 22: 343-359.

Ballantyne CK, Mccarroll D, Stone JO. 2006. Vertical dimensions and age of the Wicklow Mountains ice dome, Eastern Ireland, and implications for the extent of the last Irish Ice Sheet. Quaternary Science Reviews 25: 2048-2058.

Ballantyne CK, McCarroll D, Stone JO. 2007. The Donegal ice dome, northwest Ireland: dimensions and chronology. Journal of Quaternary Science 22: 773-783.

Ballantyne CK, Stone JO. 2015. Trimlines, blockfields and the vertical extent of the last ice sheet in southern Ireland. Boreas
44: 277-287.

Ballantyne CK, Stone JO, Fifield LK. 2009. Glaciation and deglaciation of the SW Lake District, England: implications of cosmogenic ${ }^{36} \mathrm{Cl}$ exposure dating. Proceedings of the Geologists' Association 120: 139-144.

Bard E, Rostek F, Turon J louis, Gendreau S. 2000. Hydrological Impact of Heinrich Events in the Subtropical Northeast Atlantic. Science 289: 1321-1324.

Barr ID, Lovell H. 2014. A review of topographic controls on moraine distribution. Geomorphology 226: 44-64.

Barr ID, Roberson S, Flood R, Dortch J. 2017. Younger Dryas glaciers and climate in the Mourne Mountains, Northern Ireland. Journal of Quaternary Science 32: 104-115.

Benn DI, Lukas S. 2006. Younger Dryas glacial landsystems in North West Scotland: an assessment of modern analogues and palaeoclimatic implications. Quaternary Science Reviews 25: 2390-2408.

Bickerdike HL, Ó Cofaigh C, Evans DJA, Stokes CR. 2017. Glacial landsystems, retreat dynamics and controls on Loch Lomond Stadial (Younger Dryas) glaciation in Britain. Boreas.

Birks HJB. 2001. Chironomid-inferred Lateglacial air temperatures at Whitrig Bog, southeast Scotland. Journal of Quaternary Science 15: 759-764.

Bowen DQ, Phillips FM, McCabe AM, Knutz PC, Sykes GA. 2002. New data for the Last Glacial Maximum in Great Britain and 
Ireland. Quaternary Science Reviews 21: 89-101.

Briner JP, Kaufman DS, Manley WF, Finkel RC, Caffee MW. 2005. Cosmogenic exposure dating of late Pleistocene moraine stabilization in Alaska. GSA Bulletin 117: 1108-1120.

Chiverrell RC, Thrasher IANM, Thomas GSP, Lang A, Scourse JD, Van Landeghem KJJ, McCarroll D, Clark CD, Ó Cofaigh C, Evans DJA, Ballantyne CK. 2013. Bayesian modelling the retreat of the Irish Sea Ice Stream. Journal of Quaternary Science 28: 200-209.

Çiner A, Sarıkaya MA, Yıldırım C. 2015. Late Pleistocene piedmont glaciations in the Eastern Mediterranean; insights from cosmogenic ${ }^{36} \mathrm{Cl}$ dating of hummocky moraines in southern Turkey. Quaternary Science Reviews 116: 44-56.

Clark J, Cabe AMMC, Schnabel C, Clark PU, Freeman S, Maden C, Xu S. 2009. ${ }^{10} \mathrm{Be}$ chronology of the last deglaciation of County Donegal, northwestern Ireland. Boreas 38: 111-118.

Clark CD, Ely JC, Greenwood SL, Hughes ALC, Meehan R, Barr ID, Bateman MD, Bradwell T, Doole J, Evans DJA, Jordan CJ, Monteys X, Pellicer XM, Sheehy M. 2017. BRITICE Glacial Map, version 2: a map and GIS database of glacial landforms of the last British-Irish Ice Sheet. Boreas.

Clark CD, Hughes ALC, Greenwood SL, Jordan C, Sejrup HP. 2012. Pattern and timing of retreat of the last British-Irish Ice Sheet. Quaternary Science Reviews 44: 112-146.

Coleman CG, Carr SJ, Parker AG. 2009. Modelling topoclimatic controls on palaeoglaciers: implications for inferring palaeoclimate from geomorphic evidence.
Quaternary Science Reviews 28: 249-259.

Colhoun EA, Synge MF. 1980. The Cirque Moraines at Lough Nahanagan, County Wicklow, Ireland. Proceedings of the Royal Irish Academy. Section B: Biological, Geological, and Chemical Science 80: 2545.

Colucci RR. 2016. Geomorphic influence on small glacier response to post-Little Ice Age climate warming: Julian Alps, Europe. Earth Surface Processes and Landforms 41: 1227-1240.

Crump SE, Anderson LS, Miller GH, Anderson RS. 2017. Interpreting exposure ages from ice-cored moraines: a Neoglacial case study on Baffin Island, Arctic Canada. Journal of Quaternary Science 32: 1049-1062.

Demirdag S, Yavuz H, Altindag R. 2009. The effect of sample size on Schmidt rebound hardness value of rocks. International Journal of Rock Mechanics and Mining Sciences 46: 725-730.

Dortch JM, Hughes PD, Tomkins MD. 2016. Schmidt hammer exposure dating (SHED): Calibration boulder of Tomkins et al. (2016). Quaternary Geochronology 35: 6768.

Dortch JM, Owen LA, Caffee MW. 2013. Timing and climatic drivers for glaciation across semi-arid western HimalayanTibetan orogen. Quaternary Science Reviews 78: 188-208.

Dortch JM, Owen LA, Caffee MW, Brease P. 2010. Late Quaternary glaciation and equilibrium line altitude variations of the McKinley River region, central Alaska Range. Boreas 39: 233-246.

Eynaud F, de Abreu L, Voelker A, Schönfeld J, Salgueiro E, Turon JL, Penaud A, Toucanne S, Naughton F, Sánchez Goñi 
MF, Malaizé B, Cacho I. 2009. Position of the Polar Front along the western Iberian margin during key cold episodes of the last 45 ka. Geochemistry, Geophysics, Geosystems 10.

Fabel D, Ballantyne CK, Xu S. 2012.

Trimlines, blockfields, mountain-top erratics and the vertical dimensions of the last British- Irish Ice Sheet in NW Scotland. Quaternary Science Reviews 55: 91-102.

Glasser NF, Hughes PD, Fenton C, Schnabel C, Rother H. 2012. ${ }^{10} \mathrm{Be}$ and ${ }^{26} \mathrm{Al}$ exposure-age dating of bedrock surfaces on the Aran ridge, Wales: evidence for a thick Welsh Ice Cap at the Last Glacial Maximum. Journal of Quaternary Science 27: 97-104.

Hallet B, Putkonen J. 2017. Surface Dating of Dynamic Landforms: Young Boulders on Aging Moraines. Science 265: 937-940.

Hambrey MJ, Quincey DJ, Glasser NF, Reynolds JM, Richardson SJ, Clemmens S. 2008. Sedimentological, geomorphological and dynamic context of debris-mantled glaciers, Mount Everest (Sagarmatha) region, Nepal. Quaternary Science Reviews 27: 2361-2389.

Heyman J, Stroeven AP, Harbor JM, Caffee MW. 2010. Too young or too old: Evaluating cosmogenic exposure dating based on an analysis of compiled boulder exposure ages. Earth and Planetary Science Letters 302: 71-80.

Hughes PD. 2018. Little Ice Age glaciers and climate in the Mediterranean mountains: A new analysis. Cuadernos de Investigación Geográfica 44.

Hughes PD, Braithwaite RJ. 2008. Application of a degree-day model to reconstruct Pleistocene glacial climates. Quaternary Research 69: 110-116.
Hughes PD, Gibbard PL. 2015. A stratigraphical basis for the Last Glacial Maximum (LGM). Quaternary International 383: 174-185.

Hughes PD, Glasser NF, Fink D. 2016. Rapid thinning of the Welsh Ice Cap at 2019 ka based on ${ }^{10} \mathrm{Be}$ ages. Quaternary Research 85: 107-117.

Ivy-Ochs $\mathrm{S}$, Kerschner $\mathrm{H}$, Reuther $\mathrm{A}$, Maisch M, Sailer R, Kubik PW, Synal HA, Schlüchter C. 2006. The timing of glacier advances in the northern European Alps based on surface exposure dating with cosmogenic ${ }^{10} \mathrm{Be}^{26} \mathrm{Al},{ }^{36} \mathrm{Cl}$, and ${ }^{21} \mathrm{Ne}$. In: Siame LL, In: Bourlès $\mathrm{DL}_{\text {, }}$ In: Brown ET, eds. In Situ-Produced Cosmogenic Nuclides and Quantifi cation of Geological Processes: Geological Society of America Special Paper 415. Geological Society of America, 43-60.

Ivy-Ochs $\mathrm{S}$, Kerschner $\mathrm{H}$, Reuther $\mathrm{A}$, Preusser $F$, Heine K, Maisch MAX, Kubik PW, Schlüchter C. 2008. Chronology of the last glacial cycle in the European Alps. Journal of Quaternary Science 23: 559-573.

Kelly A, Charman DJ, Newnham RM. 2010. A Last Glacial Maximum pollen record from Bodmin Moor showing a possible cryptic northern refugium in southwest England. Journal of Quaternary Science 25: 296-308.

Kern Z, László P. 2010. Size specific steadystate accumulation-area ratio: an improvement for equilibrium-line estimation of small palaeoglaciers.

Quaternary Science Reviews 29: 2781-2787.

Kirkbride MP, Winkler S. 2012. Correlation of Late Quaternary moraines: impact of climate variability, glacier response, and chronological resolution. Quaternary Science Reviews 46: 1-29.

Knight L, Boston C, Lovell H, Pepin N. 2017. 
Last Glacial-Interglacial Transition ice dynamics in the Wicklow Mountains, Ireland. Geophysical Research Abstracts 19.

Lal D. 1991. Cosmic ray labeling of erosion surfaces: in situ nuclide production rates and erosion models. Earth and Planetary Science Letters 104: 424-439.

Lloyd JM, Zong Y, Fish P, Innes JB. 2013. Holocene and Lateglacial relative sea-level change in north-west England: implications for glacial isostatic adjustment models. Journal of Quaternary Science 28: 59-70.

Lowe S. 1981. Radiocarbon dating and stratigraphic resolution in Welsh lateglacial chronology. Nature 293: 210212.

Lukas S, Graf A, Coray S, Schlüchter C. 2012. Genesis, stability and preservation potential of large lateral moraines of Alpine valley glaciers e towards a unifying theory based on Findelengletscher, Switzerland. Quaternary Science Reviews 38: $27-48$.

Macleod A, Palmer A, Lowe J, Rose J, Bryant C, Merritt J. 2011. Timing of glacier response to Younger Dryas climatic cooling in Scotland. Global and Planetary Change 79: 264-274.

Matthews JA, Owen G. 2008. Endolithic lichens, rapid biological weathering and Schmidt Hammer R-Values on recently exposed rock surfaces: Storbreen glacier foreland, Jotunheimen, Norway. Geografiska Annaler, Series A: Physical Geography 90: 287-297.

McCabe AM, Clark PU, Clark J, Dunlop P. 2007. Radiocarbon constraints on readvances of the British-Irish Ice Sheet in the northern Irish Sea Basin during the last deglaciation. Quaternary Science Reviews
26: 1204-1211.

McCarroll D, Stone JO, Ballantyne CK, Scourse JD, Fifield LK, Evans DJA, Hiemstra JF. 2010. Exposure-age constraints on the extent, timing and rate of retreat of the last Irish Sea ice stream. Quaternary Science Reviews 29: 1844-1852.

Mills SC, Grab SW, Rea BR, Carr SJ, Farrow A. 2012. Shifting westerlies and precipitation patterns during the Late Pleistocene in southern Africa determined using glacier reconstruction and mass balance modelling. Quaternary Science Reviews 55: 145-159.

Mitchell WA. 1996. Significance of snowblow in the generation of Loch Lomond Stadial (Younger Dryas) glaciers in the western Pennines, northern England. Journal of Quaternary Science 11: 233-248.

Murari MK, Owen LA, Dortch JM, Caffee MW, Dietsch C, Fuchs M, Haneberg WC, Sharma MC, Townsend-Small A. 2014. Timing and climatic drivers for glaciation across monsoon-influenced regions of the Himalayan-Tibetan orogen. Quaternary Science Reviews 88: 159-182.

Niedzielski T, Migoń P, Placek A. 2009. A minimum sample size required from Schmidt hammer measurements. Earth Surface Processes and Landforms 34: 17131725.

Ohmura A, Kasser P, Funk M. 1992.

Climate at the equilibrium line of glaciers. Journal of Glaciology 38: 397-411.

Palacios D, García-Ruiz JM, Andrés N, Schimmelpfennig I, Campos N, Léanni L, Team A. 2017. Deglaciation in the central Pyrenees during the Pleistocene e Holocene transition: Timing and geomorphological significance. Quaternary Science Reviews 162: 111-127. 
Pallàs R, Rodés Á, Braucher R, Bourlès D, Delmas M, Calvet M, Gunnell Y. 2010. Small, isolated glacial catchments as priority targets for cosmogenic surface exposure dating of Pleistocene climate fluctuations, southeastern Pyrenees. Geology 38: 891-894.

Pellitero R, Rea BR, Spagnolo M, Bakke J, Hughes P, Ivy-Ochs S, Lukas S, Ribolini A. 2015. A GIS tool for automatic calculation of glacier equilibrium-line altitudes.

Computers and Geosciences 82: 55-62.

Pellitero R, Rea BR, Spagnolo M, Bakke J, Ivy-Ochs $S$, Frew CR, Hughes P, Ribolini A, Lukas S, Renssen H. 2016. GlaRe, a GIS tool to reconstruct the 3D surface of palaeoglaciers. Computers and Geosciences 94: 77-85.

Putkonen J, Swanson T. 2003. Accuracy of cosmogenic ages for moraines.

Quaternary Research 59: 255-261.

Rea BR. 2009. Defining modern day AreaAltitude Balance Ratios (AABRs) and their use in glacier-climate reconstructions. Quaternary Science Reviews 28: 237-248.

Reimer PJ, Bard E, Bayliss A, Beck JW, Blackwell PG, Bronk Ramsey C, Buck CE, Cheng $\mathrm{H}$, Edwards RL, Friedrich $\mathrm{M}$, Grootes PM, Guilderson TP, Haflidason H, Hajdas I, Hatté $C$, Heaton TJ, Hoffman DL, Hogg AG, Hughen KA, Kaiser KF, Kromer B, Manning SW, Niu M, Reimer RW, Richards DA, Scott EM, Southon JR, Staff RA, Turney CSM, van der Plicht J. 2013. Intcal13 and marine13 radiocarbon age calibration curves 0 50,000 years cal BP. Radiocarbon 55: 1869 1887.

Shanahan TM, Zreda M. 2000. Chronology of Quaternary glaciations in East Africa. Earth and Planetary Science Letters 177: 23-42.
Smedley RK, Chiverrell RC, Ballantyne CK, Burke MJ, Clark CD, Duller GAT, Fabel D, McCarroll D, Scourse JD, Small D, Thomas GSP. 2017a. Internal dynamics condition centennial-scale oscillations in marinebased ice-stream retreat. Geology 45: 787790.

Smedley RK, Scourse JD, Small D, Hiemstra JF, Duller GAT, Bateman MD, Burke MJ, Chiverrell RC, Clark CD, Davies SM, Fabel D, Gheorghiu DM, McCarroll D, Medialdea A, Xu S. 2017b. New age constraints for the limit of the British-Irish Ice Sheet on the Isles of Scilly. Journal of Quaternary Science 32: 48-62.

Stone JO. 2000. Air pressure and cosmogenic isotope production. Journal of Geophysical Research 105: 23753-23759.

Sumner P, Nel W. 2002. The effect of rock moisture on Schmidt hammer rebound: Tests on rock samples from Marion Island and South Africa. Earth Surface Processes and Landforms 27: 1137-1142.

Tomkins MD, Dortch JM, Hughes PD. 2016. Schmidt Hammer exposure dating (SHED): Establishment and implications for the retreat of the last British Ice Sheet. Quaternary Geochronology 33: 46-60.

Tomkins MD, Huck JJ, Dortch JM, Hughes PD, Kirkbride MJ, Barr IB. 2017. Schmidt Hammer exposure dating (SHED): Calibration procedures, new exposure age data and an online calculator. Quaternary Geochronology. Accepted Manuscript.

Tonkin TN, Midgley NG, Graham DJ, Labadz JC. 2017. Internal structure and significance of ice-marginal moraine in the Kebnekaise Mountains, northern Sweden. Boreas 46: 199-211.

Warren CR. 1991. Terminal environment, topographic control and fluctuations of 
West Greenland glaciers. Boreas 20: 1-15.

Williams RBG, Robinson DA. 1983. The effect of surface texture on the determination of the surface hardness of rock using the Schmidt Hammer. Earth Surface Processes and Landforms 8: 289292.

Wilson P, Schnabel C, Wilcken KM, Vincent PJ. 2013. Surface exposure dating $\left({ }^{36} \mathrm{Cl}\right.$ and ${ }^{10} \mathrm{Be}$ ) of post-Last Glacial Maximum valley moraines, Lake District, northwest England: some issues and implications. Journal of Quaternary Science 28: 379-390.

Zech R, Glaser B, Sosin P, Kubik PW, Zech
W. 2005. Evidence for long-lasting landform surface instability on hummocky moraines in the Pamir Mountains (Tajikistan) from ${ }^{10} \mathrm{Be}$ surface exposure dating. Earth and Planetary Science Letters 237: 453-461.

\section{Figure Captions}

Figure 1. Generalised geomorphological map of the Wicklow Mountains. Moraines modified after Clark et al. (2017). ${ }^{10} \mathrm{Be}$ ages recalibrated from Ballantyne et al. (2006) using the online calculators formerly known as the CRONUS-Earth online calculator (Wrapper script 2.3, Main calculator 2.1, constants 2.3, muons 1.1; Balco et al., 2008) based on the Loch Lomond Production Rate (Fabel et al., 2012), the time-independent Lm scaling (Lal, 1991; Stone 2000) and assuming $0 \mathrm{~mm} \mathrm{ka-1}$ erosion. Ca: Camenabologue; Dj: Djouce Mountain; Ka: Kanturk; Ki: Kippure; Lq: Lugnaquillia; Mu: Mullaghcleevaun; Sc: Scarr; Tg: Tonelagee. Map projection: UTM WGS 1984.

Figure 2. Gaussian ages related to deglaciation of the Wicklow Mountains. A: The NGRIP Oxygen Isotope Curve (Rasmussen et al., 2014) plotted against $1 \sigma$ age boundaries for sampled cirque and valley sites. The Younger Dryas (YD) and Oldest Dryas (OD) periods are 
marked. B: Ice rafted debris and sea surface temperature records from cores SUBI-18 (Bard et al., 2000) and MD95-2039 (Eynaud et al., 2009) in the North Atlantic. C: Gaussian models for sampled cirque and valley sites. For each site, the highest probability Gaussian is considered the most likely timing of deglaciation as all ages are younger than the Last Glacial Maximum (Dortch et al., 2013). At Lough Nahanagan, the oldest peak with more than 3 ages is selected (c.f. Dortch et al., 2013) as this moraine is degraded and morphologically distinct from other sampled cirque moraines (MC, KL, ULB). Moreover, this estimates matches previous ${ }^{14} \mathrm{C}$ ages (Colhoun and Synge, 1980).

Figure 3. Topographic and climatic controls on the timing of cirque deglaciation in the Wicklow Mountains. A: Site Elevation; B: Snow contributing area $\left(A_{c}\right) ; C$ : Glacier area $\left(A_{g}\right)$; $D$ : $A_{c} / A_{g}$ ratio; E: ELA; F: ELAs and $A_{c} / A_{g}$ ratio plots. These data show that for large valley glaciers, retreat is paced by climate with progressive deglaciation from low to high elevation $(A)$. In contrast, marked asynchroneity in the timing of cirque deglaciation $(A)$ is strongly controlled by snow redistribution (B). This asynchroneity is weakly correlated with glacier size (C) and $A_{c} / A_{g}$ ratios $(D)$ and is unrelated to ELA (E).

Figure 4. Sampled cirque moraines at Lough Nahanagan (A), Mullaghcleevaun (B), Kelly's Lough (C) and Upper Lough Bray (D). The outer cirque moraine at Lough Nahanagan is degraded (Colhoun and Synge, 1980) and is morphologically distinct from other cirque moraines which are sharp crested, boulder-rich and matrix-poor.

Figure 5. Matrix-poor, boulder-rich moraine at Mullaghcleevaun which likely stabilised rapidly after deglaciation. 


\section{Tables}

Table 1. Gaussian ages for cirque, valley and summit sites from the Wicklow Mountains.

\begin{tabular}{|c|c|c|c|c|c|c|c|}
\hline Group & Site Name & $\begin{array}{l}\text { Site } \\
\text { Code }\end{array}$ & $\begin{array}{l}\text { Site Elevation } \\
(\mathrm{m})\end{array}$ & $\begin{array}{c}\text { Site Latitude } \\
\left({ }^{\circ}\right)\end{array}$ & $\begin{array}{l}\text { Deglaciation Age } \\
\qquad(\mathrm{ka})\end{array}$ & \pm & $\begin{array}{c}\text { Glacier Area }\left(A_{g}\right. \\
\left.\mathrm{km}^{2}\right)\end{array}$ \\
\hline \multirow{4}{*}{ Cirque } & Lough Nahanagan & LN & 443 & 53.034 & 11.38 & 0.26 & 1.10 \\
\hline & Mullaghcleevaun & MC & 571 & 53.089 & 11.40 & 0.13 & 0.61 \\
\hline & Kelly's Lough & $\mathrm{KL}$ & 585 & 52.960 & 12.00 & 0.44 & 0.38 \\
\hline & Upper Lough Bray & ULB & 466 & 53.178 & 12.31 & 0.51 & 0.35 \\
\hline \multirow{4}{*}{ Valley } & Lough Brook & LB & 393 & 53.070 & 15.41 & 0.30 & 7.63 \\
\hline & Carrawaystick Brook & CB & 421 & 52.964 & 15.48 & 0.35 & 1.83 \\
\hline & Upper Glendasan & UGD & 332 & 53.030 & 16.21 & 0.60 & 4.96 \\
\hline & Glenmacnass Waterfall & GW & 268 & 53.062 & 16.46 & 0.58 & 12.46 \\
\hline Summit & Carrigshouk & CG & 571 & 53.086 & 16.64 & 0.82 & - \\
\hline
\end{tabular}


Table 2. Snow contributing areas $\left(A_{c}\right)$, glacier areas $\left(A_{g}\right)$ and ELAs for cirque moraines.

\begin{tabular}{|c|c|c|c|c|c|c|}
\hline $\begin{array}{l}\text { Site } \\
\text { Code }\end{array}$ & $\begin{array}{l}\text { Deglaciation Age } \\
\qquad(\mathrm{ka})\end{array}$ & \pm & Snow Contributing Area $\left(A_{c} \mathrm{~km}^{2}\right)^{a}$ & $\begin{array}{l}\text { Glacier Area } \\
\left(\mathrm{A}_{g} \mathrm{~km}^{2}\right)\end{array}$ & $\begin{array}{l}A_{c} / A_{g} \\
\text { Ratio }\end{array}$ & $\mathrm{ELA}^{\mathrm{b}}$ \\
\hline LN & 11.38 & 0.26 & 1.07 & 1.10 & 0.97 & 513 \\
\hline $\mathrm{MC}$ & 11.40 & 0.13 & 0.99 & 0.61 & 1.62 & 561 \\
\hline $\mathrm{KL}$ & 12.00 & 0.44 & 0.42 & 0.38 & 1.10 & 648 \\
\hline ULB & 12.31 & 0.51 & 0.12 & 0.35 & 0.34 & 519 \\
\hline
\end{tabular}

${ }^{\mathrm{a}}$ Area within the glacier drainage basin within the $210-300^{\circ}$ quadrant + all other slopes which overlook the glacier (Gradients $\left.>25^{\circ}\right){ }^{\mathrm{b}} \mathrm{AABR}=1.9 \pm$ 0.81 (Rea, 2009) 


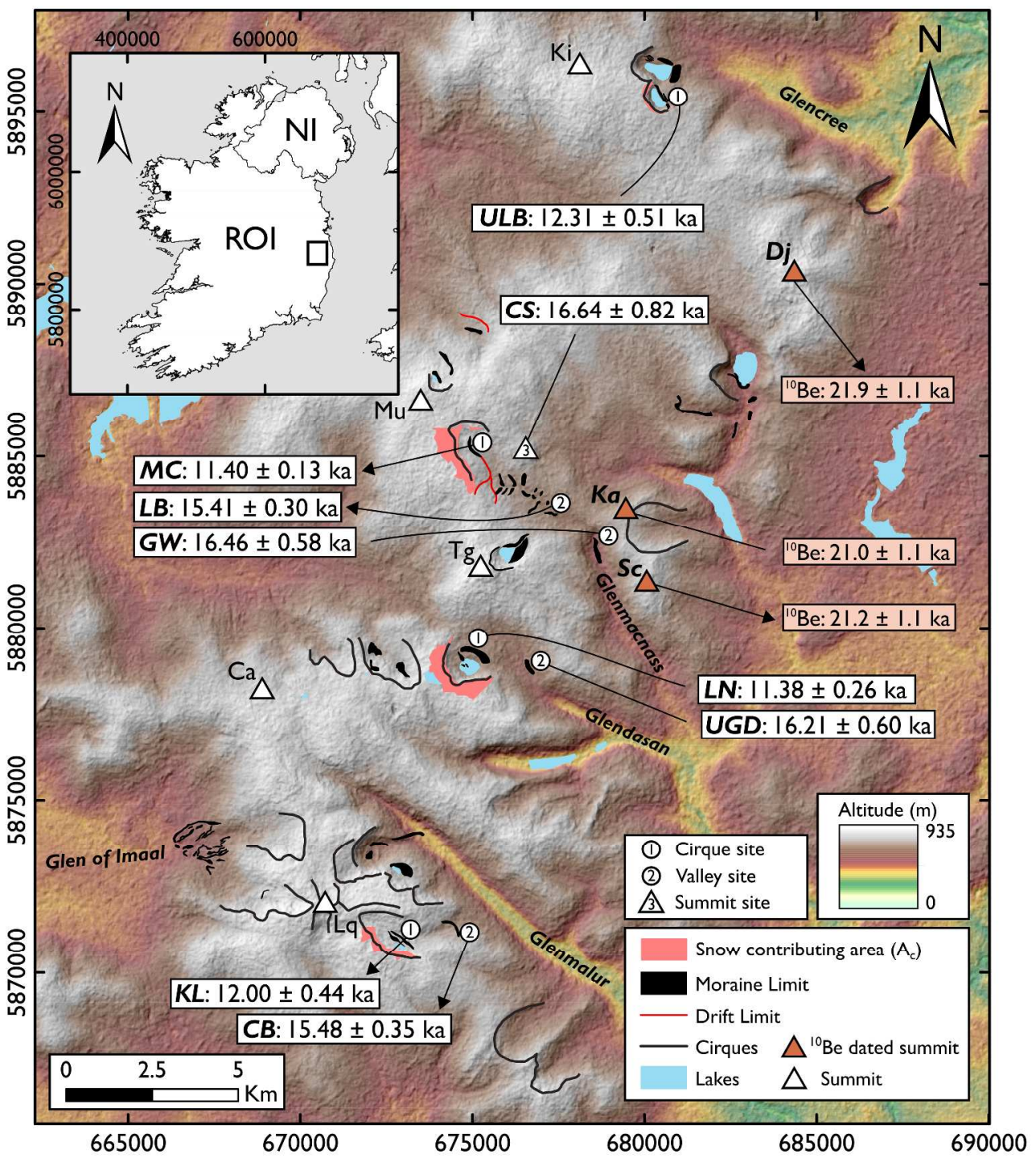

Figure 1. Generalised geomorphological map of the Wicklow Mountains. Moraines modified after Clark et al. (2017). 10Be ages recalibrated from Ballantyne et al. (2006) using the online calculators formerly known as the CRONUS-Earth online calculator (Wrapper script 2.3, Main calculator 2.1, constants 2.3, muons 1.1; Balco et al., 2008) based on the Loch Lomond Production Rate (Fabel et al., 2012), the time-independent Lm scaling (Lal, 1991; Stone 2000) and assuming 0 mm ka-1 erosion. Ca: Camenabologue; Dj: Djouce Mountain; Ka: Kanturk; Ki: Kippure; Lq: Lugnaquillia; Mu: Mullaghcleevaun; Sc: Scarr; Tg: Tonelagee. Map projection: UTM WGS 1984. 


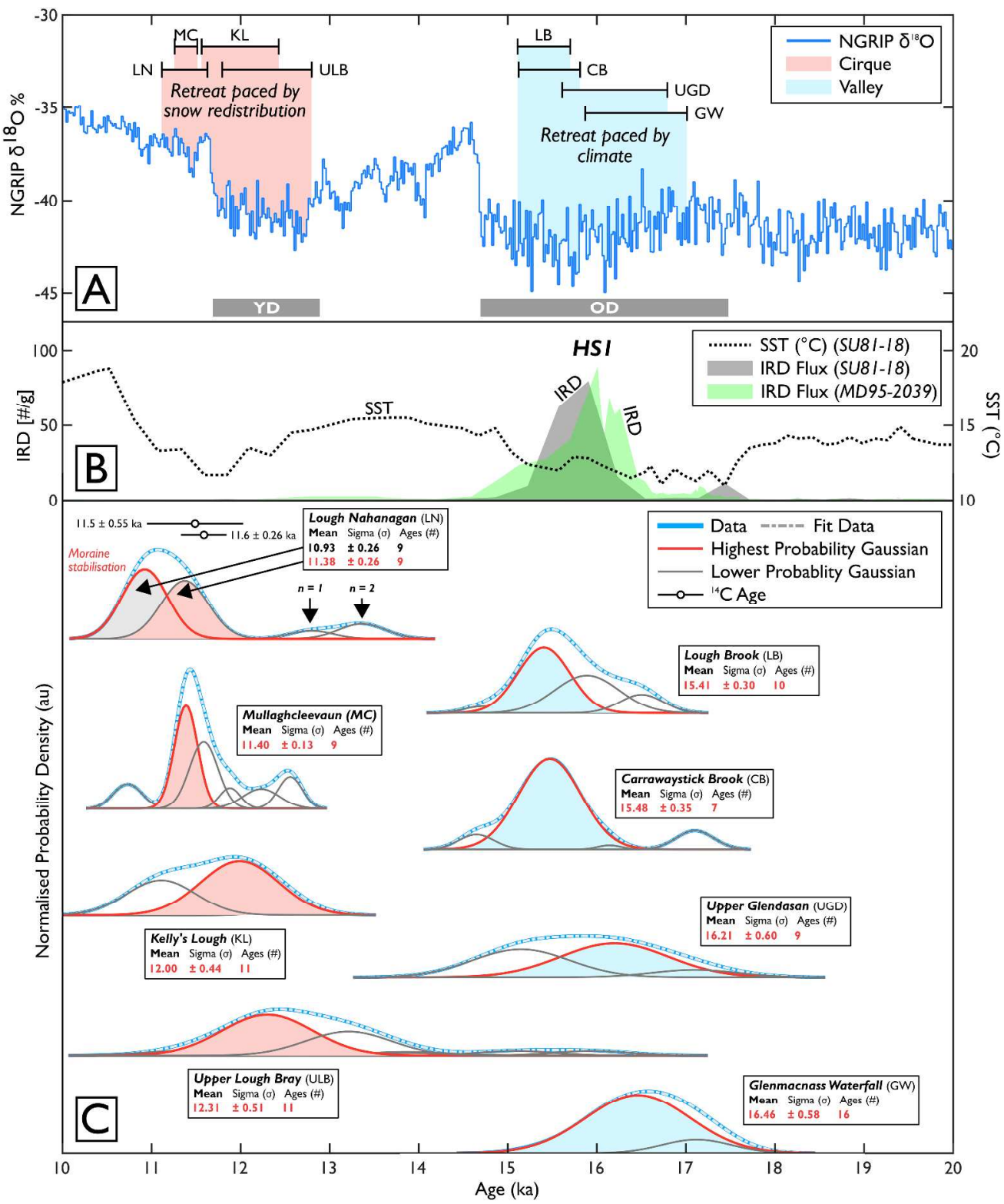

Figure 2. Gaussian ages related to deglaciation of the Wicklow Mountains. A: The NGRIP Oxygen Isotope Curve (Rasmussen et al., 2014) plotted against $1 \sigma$ age boundaries for sampled cirque and valley sites. The Younger Dryas (YD) and Oldest Dryas (OD) periods are marked. B: Ice rafted debris and sea surface temperature records from cores SUBI-18 (Bard et al., 2000) and MD95-2039 (Eynaud et al., 2009) in the North Atlantic. C: Gaussian models for sampled cirque and valley sites. For each site, the highest probability Gaussian is considered the most likely timing of deglaciation as all ages are younger than the Last Glacial Maximum (Dortch et al., 2013). At Lough Nahanagan, the oldest peak with more than 3 ages is selected (c.f. Dortch et al., 2013) as this moraine is degraded and morphologically distinct from other sampled cirque moraines (MC, KL, ULB). Moreover, this estimates matches previous 14C ages (Colhoun and Synge, 1980). 

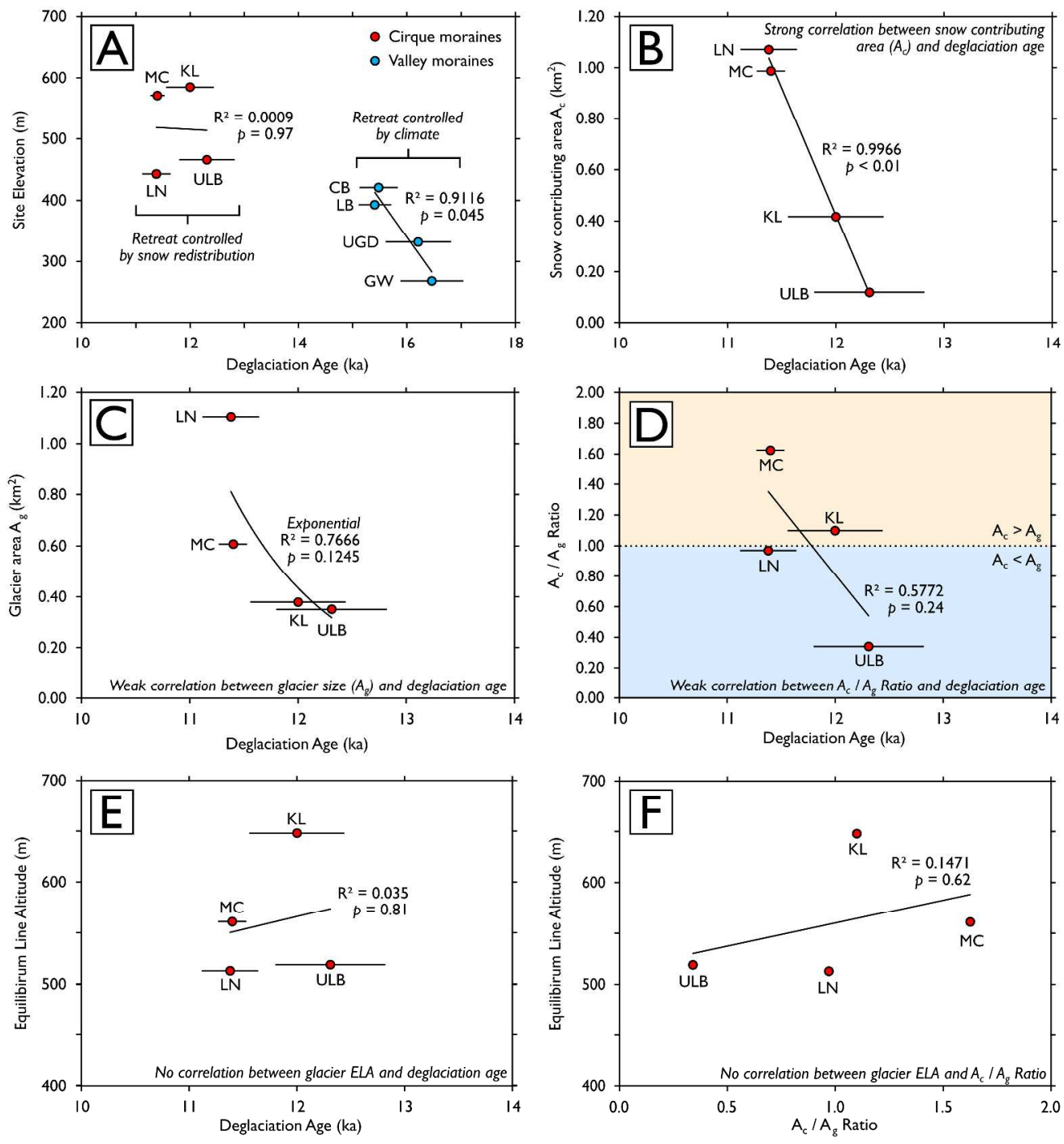

Figure 3. Topographic and climatic controls on the timing of cirque deglaciation in the Wicklow Mountains. A: Site Elevation; B: Snow contributing area (Ac); C: Glacier area (Ag); D: Ac/Ag ratio; E: ELA; F: ELAs and $\mathrm{Ac} / \mathrm{Ag}$ ratio plots. These data show that for large valley glaciers, retreat is paced by climate with progressive deglaciation from low to high elevation (A). In contrast, marked asynchroneity in the timing of cirque deglaciation $(A)$ is strongly controlled by snow redistribution (B). This asynchroneity is weakly correlated with glacier size (C) and Ac/Ag ratios (D) and is unrelated to ELA (E). 


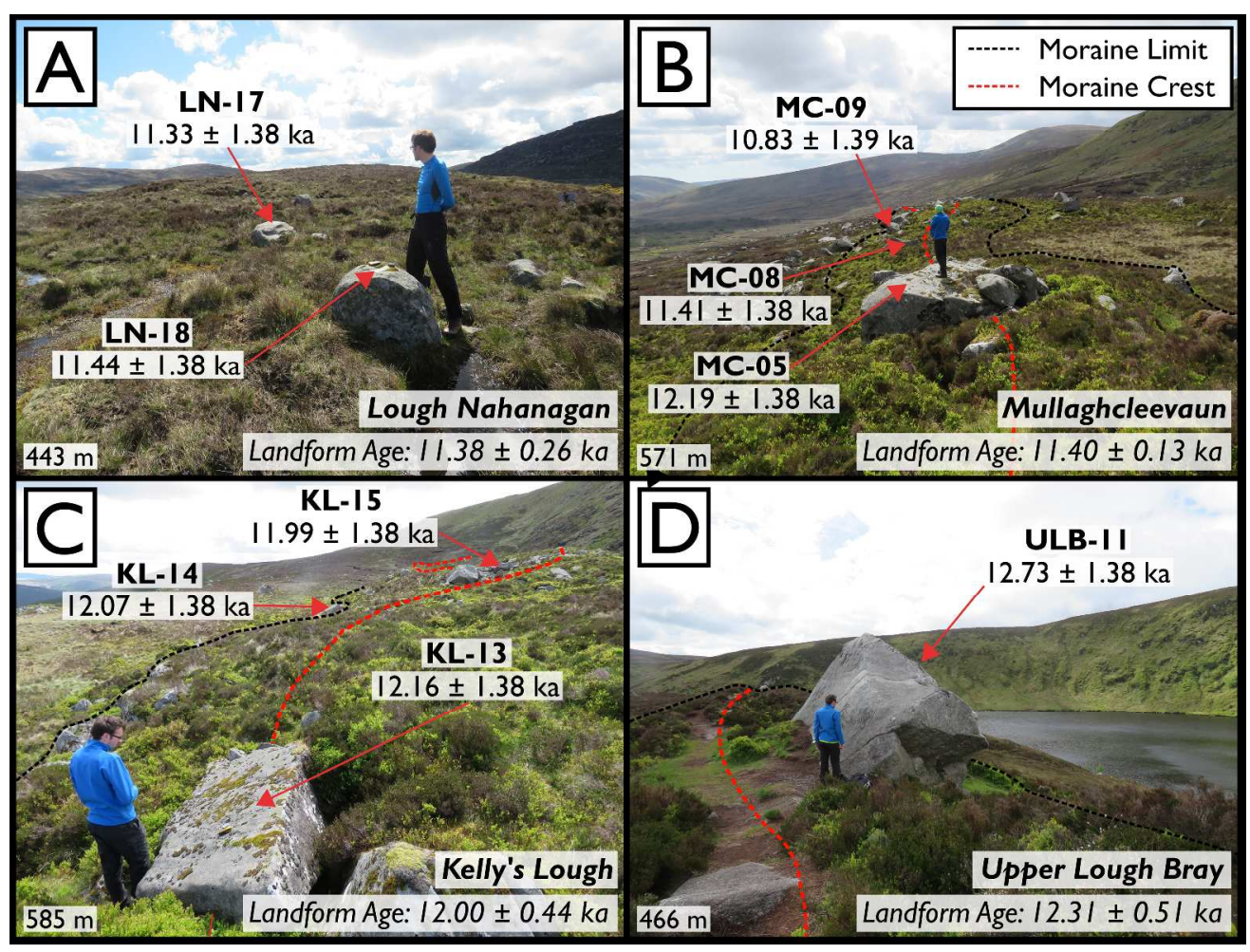

Figure 4. Sampled cirque moraines at Lough Nahanagan (A), Mullaghcleevaun (B), Kelly's Lough (C) and Upper Lough Bray (D). The outer cirque moraine at Lough Nahanagan is degraded (Colhoun and Synge, 1980) and is morphologically distinct from other cirque moraines which are sharp crested, boulder-rich and matrix-poor. 


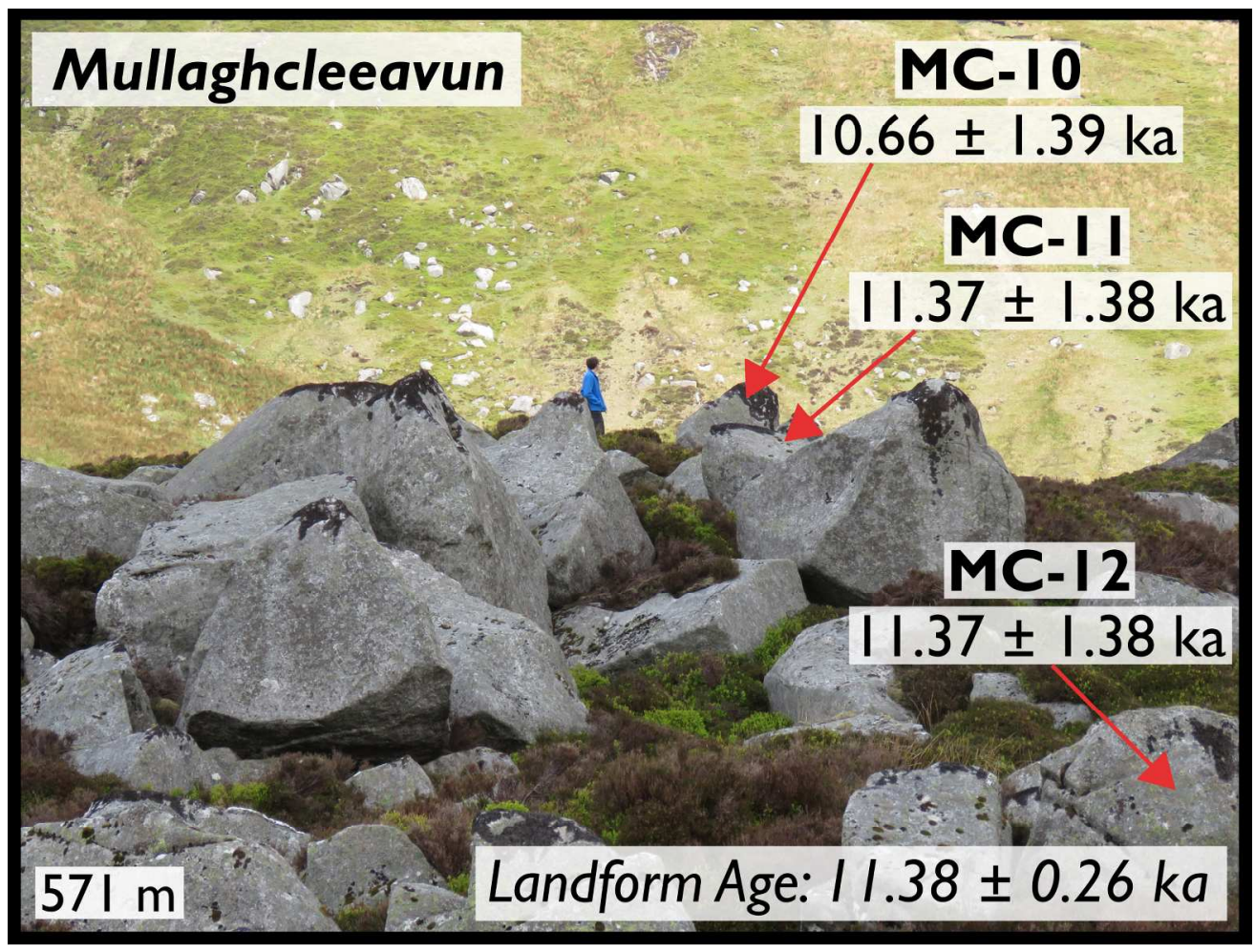

Figure 5. Matrix-poor, boulder-rich moraine at Mullaghcleevaun which likely stabilised rapidly after deglaciation. 


\begin{tabular}{|c|c|c|c|c|c|c|c|c|c|c|}
\hline Group & Site Code & Sample Name & Latitude $\left({ }^{\circ}\right)$ & Longitude $\left({ }^{\circ}\right)$ & Elevation $(\mathrm{m})$ & Type & Mean R-value & SEM $^{a}$ & Age (ka) & $1 \sigma$ \\
\hline Cirque & $\mathrm{LN}$ & LN-01 & 53.03338 & -6.3854 & 445 & Boulder & 46.10 & 0.94 & 11.535 & 1.382 \\
\hline Cirque & LN & LN-02 & 53.03352 & -6.3858 & 447 & Boulder & 46.63 & 0.92 & 11.233 & 1.383 \\
\hline Cirque & LN & LN-03 & 53.03358 & -6.38594 & 446 & Boulder & 46.24 & 0.81 & 11.46 & 1.382 \\
\hline Cirque & LN & LN-04 & 53.03383 & -6.3859 & 446 & Boulder & 46.91 & 0.91 & 11.074 & 1.384 \\
\hline Cirque & LN & LN-05 & 53.03407 & -6.38591 & 446 & Boulder & 47.28 & 0.98 & 10.852 & 1.385 \\
\hline Cirque & LN & LN-06 & 53.03402 & -6.38659 & 447 & Boulder & 47.05 & 1.04 & 10.971 & 1.384 \\
\hline Cirque & LN & LN-07 & 53.03372 & -6.3867 & 447 & Boulder & 46.42 & 0.91 & 11.322 & 1.383 \\
\hline Cirque & LN & LN-08 & 53.03381 & -6.38705 & 447 & Boulder & 42.96 & 0.64 & 13.281 & 1.378 \\
\hline Cirque & LN & LN-09 & 53.03405 & -6.38726 & 445 & Boulder & 47.16 & 0.82 & 10.892 & 1.384 \\
\hline Cirque & LN & LN-10 & 53.03421 & -6.38778 & 444 & Boulder & 42.63 & 0.55 & 13.466 & 1.377 \\
\hline Cirque & LN & LN-11 & 53.03463 & -6.38824 & 443 & Boulder & 46.54 & 0.87 & 11.252 & 1.383 \\
\hline Cirque & LN & LN-12 & 53.03461 & -6.38828 & 442 & Boulder & 47.31 & 0.95 & 10.816 & 1.385 \\
\hline Cirque & LN & LN-13 & 53.03452 & -6.38849 & 443 & Boulder & 46.18 & 1.03 & 11.46 & 1.382 \\
\hline Cirque & LN & LN-14 & 53.03478 & -6.38881 & 440 & Boulder & 47.09 & 1.05 & 10.949 & 1.384 \\
\hline Cirque & LN & LN-15 & 53.03468 & -6.38892 & 440 & Boulder & 47.09 & 0.99 & 10.949 & 1.384 \\
\hline Cirque & LN & LN-16 & 53.03476 & -6.39012 & 439 & Boulder & 47.23 & 1.10 & 10.873 & 1.384 \\
\hline Cirque & LN & LN-17 & 53.03477 & -6.39019 & 439 & Boulder & 46.43 & 0.94 & 11.327 & 1.383 \\
\hline Cirque & LN & LN-18 & 53.03462 & -6.39077 & 439 & Boulder & 46.23 & 0.82 & 11.441 & 1.382 \\
\hline Cirque & LN & LN-19 & 53.03465 & -6.39129 & 438 & Boulder & 47.01 & 0.91 & 11.005 & 1.384 \\
\hline Cirque & LN & LN-20 & 53.03481 & -6.39209 & 437 & Boulder & 43.84 & 0.82 & 12.804 & 1.379 \\
\hline Cirque & $\mathrm{MC}$ & MC-01 & 53.08932 & -6.38822 & 586 & Boulder & 45.89 & 0.85 & 11.636 & 1.382 \\
\hline Cirque & $\mathrm{MC}$ & MC-02 & 53.08923 & -6.38826 & 586 & Boulder & 45.50 & 0.79 & 11.855 & 1.381 \\
\hline Cirque & $\mathrm{MC}$ & MC-03 & 53.08913 & -6.38826 & 587 & Boulder & 46.20 & 0.76 & 11.458 & 1.382 \\
\hline Cirque & $\mathrm{MC}$ & MC-04 & 53.08889 & -6.38819 & 586 & Boulder & 44.51 & 0.79 & 12.414 & 1.38 \\
\hline Cirque & MC & MC-05 & 53.08873 & -6.38812 & 583 & Boulder & 44.92 & 0.68 & 12.188 & 1.38 \\
\hline Cirque & $\mathrm{MC}$ & MC-06 & 53.08862 & -6.38807 & 580 & Boulder & 46.21 & 0.91 & 11.452 & 1.382 \\
\hline Cirque & $\mathrm{MC}$ & MC-07 & 53.08856 & -6.38811 & 578 & Boulder & 44.19 & 0.83 & 12.599 & 1.379 \\
\hline Cirque & MC & MC-08 & 53.08836 & -6.38785 & 575 & Boulder & 46.28 & 0.87 & 11.412 & 1.383 \\
\hline
\end{tabular}




\begin{tabular}{|c|c|c|c|c|c|c|c|c|c|c|}
\hline Cirque & MC & MC-09 & 53.08817 & -6.38766 & 575 & Boulder & 47.32 & 0.90 & 10.828 & 1.385 \\
\hline Cirque & MC & MC-10 & 53.08792 & -6.38769 & 575 & Boulder & 47.62 & 0.98 & 10.657 & 1.385 \\
\hline Cirque & MC & MC-11 & 53.08784 & -6.38766 & 575 & Boulder & 46.36 & 0.77 & 11.367 & 1.383 \\
\hline Cirque & MC & MC-12 & 53.08763 & -6.38737 & 569 & Boulder & 46.37 & 1.09 & 11.371 & 1.383 \\
\hline Cirque & MC & MC-13 & 53.08737 & -6.38723 & 568 & Boulder & 45.41 & 0.96 & 11.914 & 1.381 \\
\hline Cirque & MC & MC-14 & 53.08703 & -6.38712 & 568 & Boulder & 46.28 & 0.94 & 11.418 & 1.382 \\
\hline Cirque & $\mathrm{MC}$ & MC-15 & 53.08699 & -6.38697 & 568 & Boulder & 46.12 & 0.97 & 11.513 & 1.382 \\
\hline Cirque & MC & MC-16 & 53.08677 & -6.38674 & 566 & Boulder & 45.85 & 1.04 & 11.655 & 1.382 \\
\hline Cirque & MC & MC-17 & 53.08662 & -6.38667 & 564 & Boulder & 46.42 & 0.80 & 11.341 & 1.383 \\
\hline Cirque & MC & MC-18 & 53.0861 & -6.3857 & 552 & Boulder & 46.26 & 0.87 & 11.429 & 1.382 \\
\hline Cirque & MC & MC-19 & 53.0858 & -6.38509 & 543 & Boulder & 44.24 & 0.80 & 12.571 & 1.379 \\
\hline Cirque & $\mathrm{MC}$ & MC-20 & 53.08559 & -6.38516 & 542 & Boulder & 45.90 & 0.85 & 11.63 & 1.382 \\
\hline Cirque & $\mathrm{KL}$ & KL-01 & 52.96091 & -6.42741 & 589 & Boulder & 47.09 & 0.69 & 10.964 & 1.384 \\
\hline Cirque & $\mathrm{KL}$ & KL-02 & 52.9606 & -6.42686 & 586 & Boulder & 44.40 & 0.72 & 12.491 & 1.379 \\
\hline Cirque & $\mathrm{KL}$ & KL-03 & 52.96059 & -6.42689 & 585 & Boulder & 45.40 & 0.89 & 11.918 & 1.381 \\
\hline Cirque & $\mathrm{KL}$ & KL-04 & 52.96058 & -6.42695 & 585 & Boulder & 45.01 & 0.59 & 12.151 & 1.38 \\
\hline Cirque & $\mathrm{KL}$ & KL-05 & 52.96054 & -6.42688 & 585 & Boulder & 46.57 & 0.85 & 11.252 & 1.383 \\
\hline Cirque & $\mathrm{KL}$ & KL-06 & 52.96045 & -6.42687 & 585 & Boulder & 45.31 & 0.85 & 11.961 & 1.381 \\
\hline Cirque & $\mathrm{KL}$ & KL-07 & 52.96037 & -6.42682 & 585 & Boulder & 46.28 & 0.66 & 11.414 & 1.382 \\
\hline Cirque & $\mathrm{KL}$ & KL-08 & 52.96032 & -6.42669 & 585 & Boulder & 47.08 & 0.58 & 10.962 & 1.384 \\
\hline Cirque & $\mathrm{KL}$ & KL-09 & 52.96022 & -6.42657 & 585 & Boulder & 46.59 & 0.88 & 11.24 & 1.383 \\
\hline Cirque & $\mathrm{KL}$ & $\mathrm{KL}-10$ & 52.96015 & -6.42655 & 585 & Boulder & 44.40 & 0.83 & 12.472 & 1.379 \\
\hline Cirque & $\mathrm{KL}$ & $\mathrm{KL}-11$ & 52.96006 & -6.42634 & 585 & Boulder & 45.67 & 0.81 & 11.749 & 1.381 \\
\hline Cirque & $\mathrm{KL}$ & $\mathrm{KL}-12$ & 52.9599 & -6.42618 & 585 & Boulder & 44.57 & 0.81 & 12.368 & 1.38 \\
\hline Cirque & $\mathrm{KL}$ & $\mathrm{KL}-13$ & 52.95984 & -6.42605 & 584 & Boulder & 44.94 & 0.81 & 12.162 & 1.38 \\
\hline Cirque & $\mathrm{KL}$ & $\mathrm{KL}-14$ & 52.95965 & -6.42554 & 582 & Boulder & 45.11 & 0.92 & 12.067 & 1.38 \\
\hline Cirque & $\mathrm{KL}$ & $\mathrm{KL}-15$ & 52.95945 & -6.42557 & 586 & Boulder & 45.25 & 0.97 & 11.99 & 1.381 \\
\hline Cirque & $\mathrm{KL}$ & $\mathrm{KL}-16$ & 52.95947 & -6.42537 & 585 & Boulder & 47.25 & 0.99 & 10.854 & 1.385 \\
\hline Cirque & $\mathrm{KL}$ & $\mathrm{KL}-17$ & 52.95913 & -6.42493 & 586 & Boulder & 45.56 & 0.89 & 11.819 & 1.381 \\
\hline Cirque & $\mathrm{KL}$ & $\mathrm{KL}-18$ & 52.95903 & -6.42483 & 586 & Boulder & 46.69 & 0.62 & 11.176 & 1.383 \\
\hline Cirque & $\mathrm{KL}$ & $\mathrm{KL}-19$ & 52.95883 & -6.42416 & 583 & Boulder & 45.60 & 0.74 & 11.8 & 1.381 \\
\hline Cirque & $\mathrm{KL}$ & $\mathrm{KL}-20$ & 52.95849 & -6.42373 & 583 & Boulder & 46.30 & 0.59 & 11.403 & 1.383 \\
\hline Cirque & ULB & ULB-01 & 53.18062 & -6.30129 & 464 & Boulder & 44.30 & 1.00 & 12.544 & 1.379 \\
\hline
\end{tabular}




\begin{tabular}{|c|c|c|c|c|c|c|c|c|c|c|}
\hline Cirque & ULB & ULB-02 & 53.18063 & -6.30117 & 463 & Boulder & 45.17 & 1.01 & 12.043 & 1.381 \\
\hline Cirque & ULB & ULB-03 & 53.18056 & -6.30117 & 462 & Boulder & 44.44 & 1.27 & 12.459 & 1.379 \\
\hline Cirque & ULB & ULB-04 & 53.18044 & -6.30134 & 462 & Boulder & 44.68 & 1.40 & 12.327 & 1.38 \\
\hline Cirque & ULB & ULB-05 & 53.18032 & -6.30136 & 462 & Boulder & 46.33 & 1.25 & 11.38 & 1.383 \\
\hline Cirque & ULB & ULB-06 & 53.1804 & -6.30112 & 462 & Boulder & 44.65 & 1.14 & 12.334 & 1.38 \\
\hline Cirque & ULB & ULB-07 & 53.18048 & -6.30083 & 462 & Boulder & 45.06 & 1.24 & 12.109 & 1.38 \\
\hline Cirque & ULB & ULB-08 & 53.18055 & -6.30071 & 462 & Boulder & 44.73 & 1.39 & 12.294 & 1.38 \\
\hline Cirque & ULB & ULB-09 & 53.18025 & -6.30063 & 466 & Boulder & 43.29 & 1.40 & 13.116 & 1.378 \\
\hline Cirque & ULB & ULB-10 & 53.18022 & -6.30049 & 466 & Boulder & 44.84 & 1.08 & 12.234 & 1.38 \\
\hline Cirque & ULB & ULB-11 & 53.17784 & -6.29847 & 471 & Boulder & 43.97 & 1.05 & 12.728 & 1.379 \\
\hline Cirque & ULB & ULB-12 & 53.17786 & -6.29841 & 471 & Boulder & 42.06 & 0.96 & 13.813 & 1.377 \\
\hline Cirque & ULB & ULB-13 & 53.17785 & -6.29823 & 471 & Boulder & 42.77 & 0.80 & 13.409 & 1.378 \\
\hline Cirque & ULB & ULB-14 & 53.17756 & -6.29822 & 471 & Boulder & 43.34 & 0.96 & 13.086 & 1.378 \\
\hline Cirque & ULB & ULB-15 & 53.17737 & -6.29801 & 471 & Boulder & 45.53 & 0.69 & 11.846 & 1.381 \\
\hline Cirque & ULB & ULB-16 & 53.17711 & -6.29775 & 471 & Boulder & 42.88 & 0.93 & 13.345 & 1.378 \\
\hline Cirque & ULB & ULB-17 & 53.17694 & -6.29753 & 471 & Boulder & 39.79 & 0.78 & 15.1 & 1.376 \\
\hline Cirque & ULB & ULB-18 & 53.17675 & -6.29755 & 463 & Boulder & 43.86 & 0.93 & 12.79 & 1.379 \\
\hline Cirque & ULB & ULB-19 & 53.17635 & -6.29698 & 460 & Boulder & 38.29 & 0.69 & 15.951 & 1.376 \\
\hline Cirque & ULB & ULB-20 & 53.17632 & -6.29698 & 459 & Boulder & 43.10 & 0.70 & 13.231 & 1.378 \\
\hline Valley & LB & LB-01 & 53.07045 & -6.35507 & 394 & Boulder & 37.26 & 1.04 & 16.538 & 1.377 \\
\hline Valley & LB & LB-02 & 53.07046 & -6.35512 & 393 & Boulder & 38.69 & 0.93 & 15.726 & 1.376 \\
\hline Valley & LB & LB-03 & 53.07034 & -6.35513 & 395 & Boulder & 37.59 & 0.95 & 16.345 & 1.377 \\
\hline Valley & LB & LB-04 & 53.07009 & -6.35499 & 396 & Boulder & 39.72 & 1.05 & 15.137 & 1.376 \\
\hline Valley & LB & LB-05 & 53.07006 & -6.355 & 396 & Boulder & 37.93 & 0.90 & 16.156 & 1.377 \\
\hline Valley & LB & LB-06 & 53.07009 & -6.35495 & 396 & Boulder & 39.43 & 0.72 & 15.302 & 1.376 \\
\hline Valley & LB & LB-07 & 53.07003 & -6.35471 & 396 & Boulder & 38.44 & 0.97 & 15.874 & 1.376 \\
\hline Valley & LB & LB-08 & 53.07015 & -6.3546 & 396 & Boulder & 38.71 & 0.90 & 15.715 & 1.376 \\
\hline Valley & LB & LB-09 & 53.07041 & -6.35415 & 390 & Boulder & 38.44 & 1.00 & 15.862 & 1.376 \\
\hline Valley & LB & LB-10 & 53.07045 & -6.35399 & 390 & Boulder & 40.34 & 0.82 & 14.791 & 1.376 \\
\hline Valley & LB & LB-11 & 53.07029 & -6.35407 & 392 & Boulder & 38.82 & 0.94 & 15.656 & 1.376 \\
\hline Valley & LB & LB-12 & 53.0702 & -6.35389 & 393 & Boulder & 39.35 & 0.68 & 15.357 & 1.376 \\
\hline Valley & LB & LB-13 & 53.07032 & -6.35356 & 393 & Boulder & 39.02 & 0.89 & 15.543 & 1.376 \\
\hline Valley & LB & LB-14 & 53.07028 & -6.35348 & 394 & Boulder & 38.06 & 0.65 & 16.091 & 1.376 \\
\hline
\end{tabular}




\begin{tabular}{|c|c|c|c|c|c|c|c|c|c|c|}
\hline Valley & LB & LB-15 & 53.07027 & -6.35349 & 394 & Boulder & 37.20 & 1.11 & 16.57 & 1.377 \\
\hline Valley & LB & LB-16 & 53.07012 & -6.35328 & 394 & Boulder & 39.07 & 0.80 & 15.52 & 1.376 \\
\hline Valley & LB & LB-17 & 53.07022 & -6.35302 & 391 & Boulder & 39.17 & 0.92 & 15.454 & 1.376 \\
\hline Valley & LB & LB-18 & 53.06963 & -6.35252 & 395 & Boulder & 39.37 & 0.93 & 15.34 & 1.376 \\
\hline Valley & LB & LB-19 & 53.06958 & -6.35199 & 389 & Boulder & 39.14 & 1.13 & 15.469 & 1.376 \\
\hline Valley & LB & LB-20 & 53.06971 & -6.35162 & 384 & Boulder & 39.48 & 0.79 & 15.281 & 1.376 \\
\hline Valley & CB & CB-01 & 52.96432 & -6.40324 & 423 & Boulder & 39.52 & 0.66 & 15.264 & 1.376 \\
\hline Valley & $\mathrm{CB}$ & CB-02 & 52.96429 & -6.40317 & 424 & Boulder & 39.79 & 0.79 & 15.113 & 1.376 \\
\hline Valley & $\mathrm{CB}$ & CB-03 & 52.9643 & -6.40319 & 423 & Boulder & 38.20 & 0.69 & 16.021 & 1.376 \\
\hline Valley & $\mathrm{CB}$ & CB-04 & 52.96428 & -6.4031 & 421 & Boulder & 39.36 & 0.64 & 15.359 & 1.376 \\
\hline Valley & $\mathrm{CB}$ & CB-05 & 52.96423 & -6.40311 & 421 & Boulder & 40.53 & 0.54 & 14.696 & 1.376 \\
\hline Valley & $\mathrm{CB}$ & CB-06 & 52.96421 & -6.40317 & 421 & Boulder & 38.91 & 0.80 & 15.616 & 1.376 \\
\hline Valley & CB & CB-07 & 52.96425 & -6.40302 & 420 & Boulder & 38.84 & 0.79 & 15.656 & 1.376 \\
\hline Valley & $\mathrm{CB}$ & CB-08 & 52.96436 & -6.4029 & 420 & Boulder & 36.25 & 0.70 & 17.112 & 1.378 \\
\hline Valley & $\mathrm{CB}$ & CB-09 & 52.96431 & -6.40291 & 419 & Boulder & 39.22 & 0.76 & 15.431 & 1.376 \\
\hline Valley & $\mathrm{CB}$ & CB-10 & 52.96418 & -6.40294 & 418 & Boulder & 38.79 & 0.90 & 15.662 & 1.376 \\
\hline Valley & UGD & UGD-01 & 53.02901 & -6.36507 & 336 & Boulder & 38.23 & 0.93 & 15.984 & 1.376 \\
\hline Valley & UGD & UGD-02 & 53.02903 & -6.36502 & 336 & Boulder & 37.90 & 0.91 & 16.173 & 1.377 \\
\hline Valley & UGD & UGD-03 & 53.02916 & -6.36542 & 332 & Boulder & 39.77 & 0.90 & 15.113 & 1.376 \\
\hline Valley & UGD & UGD-04 & 53.02936 & -6.3655 & 330 & Boulder & 39.07 & 0.90 & 15.51 & 1.376 \\
\hline Valley & UGD & UGD-05 & 53.02939 & -6.36557 & 330 & Boulder & 38.21 & 0.96 & 16.002 & 1.376 \\
\hline Valley & UGD & UGD-06 & 53.0296 & -6.36602 & 333 & Boulder & 37.71 & 0.73 & 16.286 & 1.377 \\
\hline Valley & UGD & UGD-07 & 53.0297 & -6.36598 & 335 & Boulder & 39.89 & 0.97 & 15.054 & 1.376 \\
\hline Valley & UGD & UGD-08 & 53.02973 & -6.36654 & 328 & Boulder & 40.46 & 0.97 & 14.731 & 1.376 \\
\hline Valley & UGD & UGD-09 & 53.02976 & -6.36657 & 329 & Boulder & 37.25 & 0.91 & 16.551 & 1.377 \\
\hline Valley & UGD & UGD-10 & 53.02974 & -6.36667 & 328 & Boulder & 36.75 & 0.68 & 16.835 & 1.377 \\
\hline Valley & UGD & UGD-11 & 53.03012 & -6.36654 & 334 & Boulder & 36.35 & 0.84 & 17.062 & 1.378 \\
\hline Valley & UGD & UGD-12 & 53.0302 & -6.36666 & 332 & Boulder & 36.26 & 0.78 & 17.115 & 1.378 \\
\hline Valley & UGD & UGD-13 & 53.03029 & -6.36672 & 333 & Boulder & 39.81 & 0.71 & 15.098 & 1.376 \\
\hline Valley & UGD & UGD-14 & 53.03049 & -6.36659 & 332 & Boulder & 38.94 & 0.82 & 15.586 & 1.376 \\
\hline Valley & UGD & UGD-15 & 53.03056 & -6.36662 & 332 & Boulder & 37.61 & 0.99 & 16.351 & 1.377 \\
\hline Valley & UGD & UGD-16 & 53.03062 & -6.36666 & 330 & Boulder & 39.21 & 1.03 & 15.423 & 1.376 \\
\hline Valley & UGD & UGD-17 & 53.03066 & -6.36667 & 330 & Boulder & 39.29 & 0.96 & 15.385 & 1.376 \\
\hline
\end{tabular}




\begin{tabular}{|c|c|c|c|c|c|c|c|c|c|c|}
\hline Valley & UGD & UGD-18 & 53.03097 & -6.367 & 330 & Boulder & 37.58 & 0.93 & 16.358 & 1.377 \\
\hline Valley & UGD & UGD-19 & 53.03113 & -6.3668 & 337 & Boulder & 39.93 & 1.12 & 15.022 & 1.376 \\
\hline Valley & UGD & UGD-20 & 53.03128 & -6.36709 & 334 & Boulder & 38.19 & 0.83 & 16.008 & 1.376 \\
\hline Valley & GW & GW-01 & 53.06269 & -6.33445 & 275 & Boulder & 37.29 & 0.97 & 16.498 & 1.377 \\
\hline Valley & GW & GW-02 & 53.06269 & -6.3345 & 274 & Boulder & 38.13 & 0.86 & 16.021 & 1.376 \\
\hline Valley & GW & GW-03 & 53.0626 & -6.33461 & 273 & Boulder & 38.36 & 1.09 & 15.891 & 1.376 \\
\hline Valley & GW & GW-04 & 53.06254 & -6.33465 & 269 & Boulder & 39.13 & 0.95 & 15.454 & 1.376 \\
\hline Valley & GW & GW-05 & 53.06248 & -6.33472 & 266 & Boulder & 35.67 & 0.72 & 17.422 & 1.378 \\
\hline Valley & GW & GW-06 & 53.06242 & -6.33468 & 271 & Boulder & 36.61 & 0.83 & 16.892 & 1.377 \\
\hline Valley & GW & GW-07 & 53.06235 & -6.33471 & 270 & Boulder & 36.35 & 0.90 & 17.044 & 1.378 \\
\hline Valley & GW & GW-08 & 53.06227 & -6.33476 & 267 & Boulder & 38.18 & 1.01 & 16.002 & 1.376 \\
\hline Valley & GW & GW-09 & 53.0622 & -6.3347 & 266 & Boulder & 35.92 & 0.81 & 17.29 & 1.378 \\
\hline Valley & GW & GW-10 & 53.06211 & -6.33465 & 268 & Boulder & 36.22 & 0.81 & 17.119 & 1.378 \\
\hline Valley & GW & GW-11 & 53.06207 & -6.33459 & 268 & Boulder & 37.16 & 1.06 & 16.589 & 1.377 \\
\hline Valley & GW & GW-12 & 53.06197 & -6.33464 & 269 & Boulder & 36.73 & 1.00 & 16.835 & 1.377 \\
\hline Valley & GW & GW-13 & 53.06182 & -6.3347 & 269 & Boulder & 37.43 & 0.94 & 16.438 & 1.377 \\
\hline Valley & GW & GW-14 & 53.06169 & -6.3347 & 268 & Boulder & 36.50 & 0.78 & 16.968 & 1.378 \\
\hline Valley & GW & GW-15 & 53.06165 & -6.33473 & 267 & Boulder & 37.27 & 0.86 & 16.532 & 1.377 \\
\hline Valley & GW & GW-16 & 53.06153 & -6.33473 & 268 & Boulder & 37.14 & 0.79 & 16.608 & 1.377 \\
\hline Valley & GW & GW-17 & 53.06144 & -6.33487 & 266 & Boulder & 37.98 & 0.74 & 16.135 & 1.377 \\
\hline Valley & GW & GW-18 & 53.0614 & -6.33493 & 262 & Boulder & 36.98 & 0.79 & 16.703 & 1.377 \\
\hline Valley & GW & GW-19 & 53.06132 & -6.33491 & 261 & Boulder & 37.72 & 0.88 & 16.286 & 1.377 \\
\hline Valley & GW & GW-20 & 53.0612 & -6.33494 & 261 & Boulder & 37.92 & 0.61 & 16.173 & 1.377 \\
\hline Summit & CS & CS-01 & 53.08641 & -6.3626 & 570 & Bedrock & 35.45 & 0.63 & 17.56 & 1.379 \\
\hline Summit & CS & CS-02 & 53.08638 & -6.36257 & 571 & Boulder & 34.01 & 0.58 & 18.389 & 1.381 \\
\hline Summit & CS & CS-03 & 53.08649 & -6.36254 & 570 & Bedrock & 35.62 & 0.73 & 17.464 & 1.378 \\
\hline Summit & CS & CS-04 & 53.08645 & -6.36234 & 570 & Bedrock & 39.11 & 0.82 & 15.478 & 1.376 \\
\hline Summit & CS & CS-05 & 53.08653 & -6.36226 & 570 & Bedrock & 39.31 & 0.80 & 15.367 & 1.376 \\
\hline Summit & CS & CS-06 & 53.08663 & -6.36216 & 570 & Boulder & 37.31 & 1.00 & 16.506 & 1.377 \\
\hline Summit & CS & CS-07 & 53.0864 & -6.36238 & 570 & Bedrock & 39.39 & 0.66 & 15.321 & 1.376 \\
\hline Summit & CS & CS-08 & 53.08634 & -6.36248 & 570 & Bedrock & 36.21 & 0.81 & 17.127 & 1.378 \\
\hline Summit & CS & CS-09 & 53.08615 & -6.36222 & 569 & Bedrock & 39.03 & 0.56 & 15.529 & 1.376 \\
\hline Summit & CS & CS-10 & 53.08611 & -6.36223 & 569 & Bedrock & 40.13 & 0.75 & 14.905 & 1.376 \\
\hline
\end{tabular}




\begin{tabular}{lllllllllll} 
Summit & CS & CS-11 & 53.08605 & -6.36221 & 567 & Bedrock & 38.09 & 0.50 & 16.059 & 1.376 \\
Summit & CS & CS-12 & 53.08595 & -6.36209 & 567 & Boulder & 37.23 & 1.02 & 16.548 & 1.377 \\
Summit & CS & CS-13 & 53.08597 & -6.36204 & 568 & Bedrock & 39.01 & 0.81 & 15.548 & 1.376 \\
Summit & CS & CS-14 & 53.086 & -6.3619 & 568 & Bedrock & 39.58 & 0.70 & 15.226 & 1.376 \\
Summit & CS & CS-15 & 53.08591 & -6.3618 & 568 & Bedrock & 36.97 & 0.94 & 16.703 & 1.377 \\
Summit & CS & CS-16 & 53.08586 & -6.36144 & 569 & Bedrock & 36.74 & 0.79 & 16.835 & 1.377 \\
Summit & CS & CS-17 & 53.08616 & -6.36171 & 569 & Bedrock & 36.67 & 0.71 & 16.871 & 1.377 \\
Summit & CS & CS-18 & 53.08634 & -6.36132 & 569 & Boulder & 37.58 & 0.99 & 16.353 & 1.377 \\
Summit & CS & CS-19 & 53.08645 & -6.36164 & 569 & Boulder & 37.25 & 0.73 & 16.544 & 1.377 \\
Summit & CS & CS-20 & 53.08644 & -6.36157 & 569 & Bedrock & 37.66 & 0.80 & 16.317 & 1.377 \\
\hline
\end{tabular}

${ }^{\text {a }}$ Standard Error of the Mean 